\title{
Fjármagnsskipan og fjárhagsleg staða fyrirtækja á Íslandi árin 2005 til 2014. Áhrif efnahagshrunsins og annarra pátta á skuldsetningu.
}

\author{
Anna Rut Práinsdóttir og Gylfi Magnússon ${ }^{1}$
}

\begin{abstract}
Ágrip
Óhófleg skuldsetning getur haft alvarleg áhrif á rekstur fyrirtækja eins og berlega kom í ljós hérlendis í efnahagshruninu. Markmiðið með pessari rannsókn er að draga upp skýra mynd af fjármagnsskipan og fjárhagslegri stöđu íslenskra fyrirtækja og sérstaklega að bæta úr skorti á rannsóknum á stöðu smærri fyrirtækja. Rannsóknarniðurstöður skiptast í prjá hluta. Í fyrsta hluta er fjárhagsleg staða og fjármagnsskipan fyrirtækja af mismunandi stærð greind með pví að bera saman gögn úr innlendum ársreikningum árin 2005 til 2014. Í öđrum hluta eru algengar kennitölur reiknaðar til að gefa skýrari mynd af próun milli ára. Áhersla er lögð á skuldsetningu en einnig eru reiknaðar kennitölur um greiðsluhæfi og arðsemi. Í priðja hluta er kannað með fjölbreytu aðhvarfsgreiningu hvaða ólíku pættir kunna að hafa áhrif á skuldsetningu svo sem stærð, aldur, efnislegar eignir, arðsemi og afskriftir. Niðurstöður sýna að skuldsetning er ráðandi fjármögnunarkostur hjá íslenskum fyrirtækjum og var skuldastaða árið 2014 svipuð pví sem hún var árin fyrir efnahagshrun. Aðstæður sem upp komu í efnahagshruninu urðu til pess að hreinar skuldir fyrirtækja jukust um tæplega 50\% árið 2008. Í lok pess árs var nær helmingur fyrirtækja í landinu með neikvætt eigið fé. Staða eignaminni fyrirtækja versnaði mun meira en peirra eignameiri. Tengsl pátta komu að einhverju leyti á óvart, en stærð og arðsemi drógu úr skuldsetningu á meðan aldur, efnislegar eignir og afskriftir juku hana. Brýnt virðist að reyna að draga úr hvötum til skuldsetningar og leggja kapp á að styrkja eiginfjárstöðu til að bæta rekstur fyrirtækja og auka fjárhagslegt svigrúm til að mæta áföllum í efnahagslífinu.
\end{abstract}

\begin{abstract}
An excessive level of debt can be very detrimental for companies as the financial crash in Iceland clearly showed. The goal of this project is to analyze the capital structure and financial position of Icelandic companies and in particular address the lack of research into the finances of small firms. The analysis is in three parts. First we look at the finances of companies, categorized by size, by analyzing financial reports from year 2005 to 2014 . Then we look at various often quoted financial indicators and analyze trends and changes over time. The

\footnotetext{
${ }^{1}$ Anna Rut lauk MS gráðu í fjármálum fyrirtækja frá viðskiptafræðideild Háskóla Íslands í febrúar 2016 og er rannsókn pessi byggð á meistararitgerð hennar. Gylfi er dósent í viðskiptafræðideild Háskóla Íslands. Höfundar vilja pakka Creditinfo fyrir að veita góðfúslega aðgang að gögnum sem stuðst var við í rannsókninni og tveimur ritrýnum fyrir gagnlegar ábendingar.
}

This work is licensed under a Creative Commons Attribution 4.0 License. 
emphasis is on measures related to debt but we also look at indicators on solvency and profitability. Finally, we use multi-variable regression analysis to determine what factors can explain debt levels, including size, age, tangible assets, profitability and depreciation and amortization. We find that debt is the prevailing method of financing for Icelandic companies and that debt levels in 2014 were similar to those seen before the crash of 2008. The crash led to an increase of net debt of Icelandic companies by almost $50 \%$ in 2008 . At the end of the year almost half of Iceland's companies had negative equity. Asset poor companies were hit harder than their counterparts that had more substantial assets, showing well how vulnerable companies with little equity are in a downturn. The regressions returned some surprising results. Large size and profitability seemed to lead to lower debt levels while a longer life span, substantial tangible assets and high levels of depreciation and amortization seemed to lead to increased debt. We conclude that it is vital for the Icelandic economy to reduce incentives to debt financing, replacing it with higher equity levels to improve the health of Icelandic companies and prepare them better for economic shocks in a shock-prone economy.

\section{JEL flokkun: G01, G31}

Lykilorð: Fjármagnsskipan, fjárhagsleg endurskipulagning

\section{Inngangur}

\subsection{Fjármögnunarumhverfið á Íslandi síðasta áratug}

Fyrstu ár nýrrar aldar, í aðdraganda hrunsins, stækkuðu efnahagsreikningar fyrirtækja hérlendis umtalsvert. Var skuldaaukning mikil, meðal annars vegna auðvelds aðgengis að lánsfé á hagstæðum kjörum. Falli fjármálakerfisins fylgdi snörp gengislækkun íslensku krónunnar sem leiddi til aukinnar verðbólgu. Samhliða pví dró verulega úr innlendri eftirspurn. Höfðu pessar ytri aðstæður mikil áhrif á fjárhagslega stöðu og fjármagnsskipan fyrirtækja skömmu eftir hrun. Skuldsetning jókst enn meira og greiðslubyrði gengis- og verðtryggðra lána pyngdist. Fjármögnun varð afar erfið en bankakerfið var illa starfhæft og gat ekki með góðu móti veitt fyrirtækjum pá pjónustu sem pau purftu. Nafnvaxtastig hækkaði tímabundið og voru áhættulitlir vextir á innlánsreikningum mjög háir fram yfir fyrsta ársfjórðung 2009. Náðu innlán innlendra aðila í bankakerfinu sögulegu hámarki í september sama ár (Seðlabanki Íslands, 2011b). Lítil velta var á innlendum hlutabréfamarkaði á pessum tíma og fá fyrirtæki skráð á markað. Víðtæk gjaldeyrishöft og takmarkaður trúverðugleiki íslenska hagkerfisins útilokuðu erlenda fjármögnun. Varð takmarkað aðgengi fjármagns alvarlegasta hindrunin í rekstri fyrirtækja hér á landi árin 2008-2009 (Seðlabanki Íslands, 2011b; Viðskiptaráð Íslands, 2009; World Economic Forum, 2009). Lítil og meðalstór fyrirtæki, sem eiga almennt ekki jafnmikla möguleika á fjármögnun með útgáfu hluta- og skuldabréfa á skipulögðum verðbréfamarkaði og stór, fundu sérstaklega fyrir skorti á fjármagni. Fjármögnun peirra einskorðaðist við lántökur og fyrirgreiðslur í bönkum á háum vöxtum. Virtist framboði lánsfjármagns frá bankakerfinu ekki vera ábótavant, sem er öfugt við pað sem tíðkaðist erlendis, heldur voru fyrirtækjum settar pröngar skorður með óhagstæðum vöxtum (OECD, 2015b; OECD, 2015c; Viðskiptaráð Íslands, 2009). Pá torveldaði lítið eigið fé iðulega lántöku.

Að mati Alpjóða gjaldeyrissjóðsins varð efnahagslægðin á Íslandi dýpri en ella vegna pess hve skuldsetning fyrirtækja var mikil í aðdraganda efnahagshrunsins (2010). Eftir hrun hefur pví verið lögð talsverð áhersla á að draga úr skuldsetningu í peim tilgangi að auka getu 
fyrirtækja til að standa við skuldbindingar prátt fyrir efnahagssveiflur og önnur áföll. Efnahagsreikningar fjölmargra fyrirtækja voru endurskipulagðir með aðstoð fjármálafyrirtækja og annarra kröfuhafa. Ákveðin skilyrði voru sett sem áttu að hraða endurreisn og viðhalda samkeppni á markaði. Meðal annars máttu fjármálafyrirtæki einungis koma rekstrarhæfum fyrirtækjum til bjargar, draga purfti úr skuldabyrði og fyrirtæki undir yfirráðum bankanna varð að reka á eðlilegum arðsemisgrundvelli og í eins skamman tíma og mögulegt var (Samkeppniseftirlitið, 2013). Skuldir voru afskrifaðar eða færðar niður til samræmis við virði fyrirtækjanna og greiðslugetu. Pá voru gengistryggð lán endurreiknuð og leiðrétt í kjölfar dóma um ólögmæti verðtryggingar í formi gengistryggingar lána² sem höfðu verið verulega ípyngjandi fyrir mörg peirra. Var víða reynt að leita leiða til að greiða niður skuldir og í einhverjum tilvikum var skuldum breytt í hlutafé sem selt var öðrum (Samkeppniseftirlitið, 2012).

Á árunum 2010 og 2011 dró umtalsvert úr skuldsetningu fyrirtækja með pessum aðgerðum. En pótt fjöldinn allur af stærri fyrirtækjum landsins hafi lokið fjárhagslegri endurskipulagningu í árslok 2011 og mörg hver hafi fengið leiðréttingu vegna ólögmætra gengistryggðra lánasamninga, voru enn vísbendingar um að endurreisn atvinnulífsins gengi of hægt. Frá bankahruni hafði lítil sem engin virkni verið á markaði með fyrirtækjaskuldabréf stærri fyrirtækja. Prátt fyrir mikla vaxtalækkun Seðlabankans frá ársbyrjun 2009 voru útlánsvextir fjármálastofnana enn tiltölulega háir og aðgengi að lánsfé takmarkað (Seðlabanki Íslands, 2011b). Erfitt er að henda reiður á hver staða smærri fyrirtækja var á peim tíma. Ljóst er pó að gjaldprotum og árangurslausum fjárnámum hafði fjölgað gríðarlega enda var ekki búið að leysa úr skuldavanda fyrirtækja (Hagstofa Íslands, 2015c; Samkeppniseftirlitið, 2012; Viðskiptaráð Íslands, 2009).

Næstu prjú árin átti skuldastaðan eftir að batna til muna. Engu að síður bendir ýmislegt til að íslensk fyrirtæki séu enn skuldum hlaðin og staða peirra ekki eins og best verður á kosið (OECD, 2015a; Steinn Friðriksson, 2015). Í nýlegri könnun á stöðu fyrirtækja og efnahagsumhverfis kom meðal annars fram að um prír af hverjum fjórum fjármálastjórum 300 stærstu fyrirtækja landsins töldu fyrirtæki of skuldsett og tæplega helmingur að líkleg próun næstu 12 mánaða yrði að draga úr skuldsetningu. Meiri hluti aðspurðra taldi framboð af lánsfé yfirdrifið en kostnað við pað of háan og virðist sú staða pví lítið hafa breyst frá efnahagshruni.

\footnotetext{
${ }^{2}$ Fjölmargir dómar hafa fallið í Hæstarétti sem tengjast ólögmæti pess að binda lán sem gerð eru í íslenskum krónum við gengi erlendra gjaldmiðla. Slík gengistrygging var dæmd óskuldbindandi par sem hún brýtur í bága við ákvæði VI. kafla laga nr. 38/2001 um vexti og verðtryggingu. Til dæmis komst Hæstiréttur að peirri niðurstöðu í dómi frá 9. júní 2011 í máli nr. 155/2011 að svo kölluð jafnvirðislán, par sem fjölmyntalán að jafnvirði tiltekinnar fjárhæðar í íslenskum krónum voru tekin í tilgreindum erlendum myntum væru lán með ólögmætri gengistryggingu. Ríkti veruleg óvissa pessu tengd í nokkurn tíma. Leitast var við að tryggja samræmda meðferð pessara mála með breytingum á lögum, sbr. lög nr. 151/2010, en ýmis álitamál hafa pó komið til úrlausnar dómstóla á undanförnum árum.

${ }^{3}$ Vextir á veðlánum náðu hámarki á fyrsta ársfjórðungi 2009, en lækkuðu svo um 13,75 prósentustig og náđu lágmarki í febrúar 2011. Vextir á innlánsreikningum urðu hæstir 17,5\% og lækkuðu í 3,25\% í febrúar 2011 (Seðlabanki Íslands, 2015c). Ástæðu pess að peningastefnan skilaði sér ekki í lækkun útlánsvaxta til fyrirtækja nema að hluta má meðal annars rekja til óvissu um fjárhagslegan styrk fjármálafyrirtækja, gæði eigna og auknar álögur á bankarekstur, auk pess sem almennar efnahagshorfur voru ekki mjög góðar (Seðlabanki Íslands, 2011b). Pá er vert að taka fram að í upphafi annars ársfjórðungs 2009 byrjaði verð hlutabréfavísitalna (t.d. OMXI8) að hækka hægt á ný (Nasdaq OMX Nordic, 2015).
} 
Pá töldu prír af fjórum útgáfu nýs hlutafjár hagkvæma fjármögnunarleið fyrir fyrirtæki miðað við aðstæður (Deloitte, 2015).

Sveiflur í fjármögnunarumhverfinu undanfarinn áratug hafa verið mjög áberandi og varla farið framhjá nokkrum. Fáar rannsóknir hafa pó verið gerðar hér á landi á fjármögnun og fjármagnsskipan fyrirtækja. Ná flestar peirra aðeins yfir stærri félög eða pau sem eiga kost á fjármögnun á skipulögðum verðbréfamörkuðum en lítil og meðalstór fyrirtæki hafa hlotið litla umfjöllun. Eru pau pó um 99\% af fjölda starfandi fyrirtækja hérlendis og má pví segja að pau séu meginuppistaðan í íslensku atvinnulífi (Viðskiptaráð Íslands, 2009). Er markmiðið með pessari rannsókn meðal annars að bæta úr peim annmarka og varpa ljósi á fjárhagslega stöðu og fjármagnsskipan peirra ólíku fyrirtækja sem íslenskt atvinnulíf byggist á.

\subsection{Kenningar um fjármagnsskipan fyrirtækja}

Ef litið er til peirra fjölmörgu fræðikenninga sem settar hafa verið fram um fjármagnsskipan fjalla pær í meginatriðum um val pess að fjármagna fyrirtæki með skuldum við lánardrottna eða eigendur í formi eigin fjár. Pær snúast oft um að reyna að finna pá samsetningu ólíkra tegunda skulda og eigin fjár sem höfðar mest til fjárfesta og sem hámarkar markaðsvirði fyrirtækisins. Pá er einnig litið til pess hvort lán séu tekin til langs eða skamms tíma. Ólíkar fjármögnunarleiðir hafa í för með sér mismunandi skilmála svo sem vaxtakjör og tegund greiðslna en meginmunurinn felst pó í pví hvaða stöðu fjármagnseigendur hafa við uppgjör fari fyrirtækið í prot.

Verður hér farið stuttlega yfir fræðilega undirstöðu og hvaða pýðingu kenningarnar hafa fyrir skuldsetningu fyrirtækja. Er einnig fjallað um hversu vel pær eiga við um fjármagnsskipan minni fyrirtækja sem eiga ekki kost á útgáfu skulda og hlutafjár á skipulögðum verðbréfamarkaði. Að lokum eru settar fram tilgátur og markmið með rannsókninni.

\subsubsection{Kenning Modigliani og Miller (1958 og 1963)}

Sá skilningur sem er útbreiddastur á fjármagnsskipan fyrirtækja í dag byggir að verulegu leyti á tímamótakenningu Modigliani og Miller frá árinu 1958 (theory of investment). Samkvæmt kenningu peirra er meðalfjármagnskostnaður og par af leiðandi markaðsvirði fyrirtækis óháð fjármagnsskipan pess, að pví gefnu að fjármagnsmarkaður sé fullkomlega skilvirkur og að lögmálið um eitt verð gildi. Peir sýndu fram á að heildarvirði fyrirtækja ræðst af virði bæði hlutafjár og skulda, eða væntri ávöxtun allra eigna fyrirtækisins samanlagt (Modigliani og Miller, 1958). Af pví leiðir að ekki er hægt að draga úr fjármagnskostnaði með pví að skuldsetja fyrirtækið í auknum mæli pví við pað eykst áhætta skulda sem gerir pað að verkum að hlutafjáreigendur krefjast hærri áhættupóknunar. Fjármagnsskipan fyrirtækis hefur pess vegna ekki áhrif á meðalfjármagnskostnað pess eða virði (Modigliani og Miller, 1958).

Ýmsar fræðikenningar voru settar fram í kjölfarið par sem reynt var að gefa sér raunhæfari forsendur. Forsendan um fullkomna fjármálamarkaði pýðir meðal annars að utanaðkomandi fjárfestar hafa aðgang að sömu upplýsingum um fyrirtæki og stjórnendur peirra sem er vart raunhæft. Pá er ekki gert ráð fyrir páttum eins og viðskiptakostnaði, gjaldprotakostnaði og sköttum. Gerðu Modigliani og Miller (1963) sjálfir tilraun til að bæta kenningu sína með tilliti til áhrifa skattahagræðis vegna skuldsetningar. Peir héldu pví fram að skattar hefðu meiri áhrif á val fjármögnunarleiða en gert var ráð fyrir í fyrstu, pví stjórnendur gætu lækkað fjármagnskostnað og par af leiðandi aukið markaðsvirði fyrirtækja sem nemur núvirði skattahagræðis með pví að auka skuldsetningu. Eins og peir sjálfir bentu á gerir kenningin ekki ráð fyrir kostnaði vegna fjárhagserfiðleika og töldu peir núvirði skattahagræðis „einu 
varanlegu yfirburði“ pess að nota skuldir við fjármögnun (Modigliani og Miller, 1963, bls. 434). Varð pessi viðbót Modigliani og Miller um áhrif skattahagræðis á fjármagnsskipan kveikjan að fórnarskiptakenningunni sem rekja má til Kraus og Litzenberger (1973).

\subsubsection{Fórnarskiptakenningin}

Með fórnarskiptakenningunni (trade-off theory) er gert ráð fyrir að fyrirtæki hafi tiltekna kjörfjármagnsskipan sem er breytileg milli fyrirtækja og að val á fjármögnunarleið til að hámarka virði snúist um að vega og meta núvirði skattahagræðis vegna skulda og kostnaðar vegna gjaldprota. Af kenningunni leiðir að skuldsetja eigi fyrirtæki par til jaðarábati vegna skattahagræðis skuldsetningar er jafn jaðarkostnaði vegna gjaldprota en pað er sú fjármagnsskipan sem hámarkar virði pess (Kraus og Litzenberger, 1973).

Samkvæmt fórnarskiptakenningunni eru skuldir ekki áhættulausar en pó eru líkur á að lenda í fjárhagslegum erfiðleikum og kostnaði peim tengdum raunverulega eina ástæða pess að stilla skuldsetningu í hóf. Skattalöggjöf margra landa felur í sér skattahagræði skulda, sem skapar ákveðna bjögun eða slagsíðu í fjármagnsskipan fyrirtækja skuldsetningu í vil. Skekkjan stafar af pví að fyrirtækjum er heimilt að draga vaxtagjöld frá rekstrartekjum við útreikning á skattstofni. Arðgreiðslur til eigenda nýtast ekki til frádráttar skatti og myndast pví hvati fyrir stjórnendur til að skuldsetja fyrirtækin. Afleiðingin verður sú að fjármagnsskipan fyrirtækja stjórnast ekki af pörfum rekstrar heldur ráða skattalegar ástæður skuldsetningu peirra. Er pessi hvati innbyggður í skattalöggjöf hérlendis en samkvæmt 1. tl. 31. gr. laga nr. 90/2003 um tekjuskatt er fyrirtækjum unnt að draga vaxtagreiðslur lánsfjármagns frá tekjum af atvinnurekstri til lækkunar á skattstofni. Lög um tekjuskatt heimila hins vegar ekki sambærilegan skattafrádrátt af arðgreiðslum til einstaklinga (sbr. 11. gr. sömu laga) og telst arður til skattskyldra tekna. ${ }^{4}$

Fórnarskiptakenningin getur skýrt mismunandi skuldsetningarhlutfall og kjörfjármagnsskipan ólíkra fyrirtækja (sjá Graham og Harvey, 2001), en draga má pá ályktun að stór fyrirtæki með mikið af efnislegum eignum og næga arðsemi poli hærri skuldsetningu en önnur. Kenningin nær pó ekki að skýra hvers vegna arðsöm fyrirtæki hafa tilhneigingu til að bera litlar skuldir og fjármagna sig fyrst og fremst með eigin fé (Fama og French, 2002).

\subsubsection{Röðun fjármögnunarkosta}

Kenningin um röðun fjármögnunarkosta (pecking order theory) skýrir hvers vegna arðbær fyrirtæki hafa tilhneigingu til að vera minna skuldsett en önnur. Hún byggir í stuttu máli á peim forsendum að stjórnendur hafi betra aðgengi að upplýsingum um virði fyrirtækjanna og framtíðarhorfur en utanaðkomandi fjárfestar og að peir taki ákvarðanir sínar núverandi hluthöfum í hag (Myers, 1984; Myers og Majluf, 1984). Samkvæmt kenningunni miða fyrirtæki ekki að pví að ná kjörfjármagnsskipan en vegna peirra neikvæðu skilaboða sem val á fjármögnun með útgáfu hlutafjár sendir markaðnum um yfirverð hluta, reyna stjórnendur fyrst að nýta innri sjóði félagsins, gefa út skuldir ef peir nægja ekki og velja útgáfu hlutafjár sem afarkost. Flest fyrirtæki eru fjármögnuð bæði með innra og ytra fjármagni, en almennt er hlutafé talið dýrara en lánsfjármagn. Gengur pessi forgangsröðun með öðrum orðum út á að

\footnotetext{
${ }^{4}$ Málin flækjast til muna sé tekið tillit til pess að skatthlutföll eru mjög mismunandi á milli landa. Pannig er algengt að fjármagna starfsemi í löndum með háan tekjuskatt að litlu leyti með eigin fé en pess í stað með miklum skuldum við móðurfyrirtæki í lágskattalandi. Pannig er hægt að eyða hagnaði af rekstri í háskattalandinu með vaxtagreiðslum innan samstæðunnar og komast hjá tekjuskattsgreiðslum. •að er pó fyrir utan efni pessarar greinar að fjalla frekar um pennan flöt málsins.
} 
lágmarka fjármögnunarkostnað og hámarka virði félagsins (Myers, 1984; Myers og Majluf, 1984).

\subsubsection{Umboðsvandi}

Umboðsvandi (agency cost) er talinn geta haft víðtæk áhrif á val fjármögnunarleiða. Hann verður til við að stjórnendur sem starfa í umboði hluthafa reyna einnig að hámarka eigin afkomu og freistast til að taka ákvarðanir í eigin págu fremur en hluthafa. Skuldsetning getur komið í veg fyrir að stjórnendur freistist til að nota sjóðstreymi í eigin págu (Jensen, 1986). Annars konar umboðsvandi myndast pó við skuldsetningu, en stjórnendur mikið skuldsettra fyrirtækja í fjárhagsvanda geta freistast til að taka ákvarðanir sem færa virði frá lánardrottnum til eigenda (Jensen, 1986; Jensen og Meckling, 1976). Sú tegund umboðsvanda kemur til vegna pess að eigendur skulda eru framar hluthöfum í kröfuröð við útgreiðslu úr protabúum (sjá lög um gjaldprotaskipti ofl. nr. 21/1991) og eru líkur á endurheimtum höfuðstóls lánveitingar umtalsvert meiri en hlutafjár sem er jaðarkrafa við gjaldprot. Mismunandi freistnivandi er mikilvægur í umræðunni um fjármagnsskipan fyrirtækja, en óbeinan kostnað vegna fjárhagsörðugleika má að mestu rekja til umboðsvanda (Myers, 2003).

\subsection{Tilgangur og markmið}

Umfjöllun um fjármagnsskipan og fjárhagslega stöðu fyrirtækja hérlendis hefur að miklu leyti einskorðast við stór fyrirtæki. Stærstu fyrirtækin hafa að jafnaði aðgang að skilvirkum fjármálamörkuðum og eiga kost á fjármögnun með útgáfu hluta- og skuldabréfa. Skortur hefur verið á gögnum um skuldsetningu fyrirtækja af mismunandi stærð og er eins og pjóðhagslegt mikilvægi smárra og meðalstórra félaga vilji stundum gleymast. Pessari rannsókn er ætlað að bæta úr pví og varpa ljósi á fjárhagslega stöðu peirra ólíku fyrirtækja sem knýja íslenskt atvinnulíf og pá pætti sem hafa áhrif á fjármagnsskipan peirra. Rannsökuð eru áhrif efnahagshrunsins á fyrirtækin í landinu, meðal annars hvort peim hafi tekist að laga sig að breyttu efnahagsumhverfi og greiða úr skuldavanda sínum eftir hrun.

Markmiðið með rannsókninni er með öðrum orðum að varpa ljósi á fjárhagslega stöðu og fjármagnsskipan fyrirtækja á Íslandi árin 2005 til 2014, greina hana eftir stærð og kanna hvaða pættir hafa helst áhrif á skuldsetningu peirra á mismunandi tíma. Greiningin skiptist í prjá hluta. Í fyrsta hluta er fjárhagsleg staða og fjármagnsskipan fyrirtækja af mismunandi stærð greind með pví að bera saman gögn úr ársreikningum innlendra fyrirtækja árin 2005 til 2014. Er sérstakri athygli beint að áhrifum efnahagshrunsins. Í öðrum hluta eru algengar kennitölur reiknaðar til að gefa skýrari mynd af fjárhagslegri stöðu íslenskra fyrirtækja og próun hennar milli ára. Notast er við bókfærðar tölur og er áhersla lögð á fjárhagslega vogun en einnig eru reiknaðar kennitölur um greiðsluhæfi og arðsemi. Eru algild viðmið um skuldsetningu, greiðsluhæfi og arðsemi höfð til hliðsjónar. Í priðja hluta er kannað hvaða ólíku pættir eða eiginleikar fyrirtækjanna kunna að hafa áhrif á skuldsetningu svo sem stærð, aldur, efnislegar eignir, arðsemi og afskriftir. Niðurstöður eru skoðaðar í ljósi kenninga og fyrri rannsókna um fjármagnsskipan fyrirtækja.

Samkvæmt fórnarskiptakenningunni eru stór fyrirtæki sem hafa lengri rekstrarsögu síður líkleg til að verða gjaldprota og pví ættu pau að bera hærri skuldabyrði. Röðun fjármögnunarkosta segir fátt um stærð fyrirtækja og pað sama má segja um aldur peirra, en kenningin er yfirleitt túlkuð pannig að stærri fyrirtæki og eldri ættu síður að kljást við ósamhverfar upplýsingar og eiga pví frekar kost á að fjármagna sig með eigin fé. Eins og vikið var að í upphafi virðist aðgangur smárra fyrirtækja hérlendis að fjármagni vera mjög takmarkaður og er líklega töluverð hindrun í rekstri peirra og fjármögnun. Rannsóknir á bæði 
stórum og smáum fyrirtækjum hafa leitt í ljós að stærri fyrirtæki hafa tilhneigingu til að vera skuldsettari en pau smærri (t.d. Brav, 2009; Fama og French, 2002; Frank og Goyal, 2003; Hall, Hutchinson og Michaelas, 2000, 2004; Michaelas, Chittenden og Poutziouris, 1999; Rajan og Zingales, 1995; Sogorb-Mira, 2005). Eldri fyrirtæki eru oftast minna skuldsett en pau yngri (t.d. Brav, 2009; Hall ofl., 2000; Michaelas ofl., 1999; Leary og Roberts, 2010). Fyrstu tvær tilgáturnar eru pví:

\section{T1: Stærð hefur jákvæð tengsl við langtímaskuldir og heildarskuldir}

T2: Aldur hefur neikvæð tengsl við langtímaskuldir og heildarskuldir

Í samræmi við bæði fórnarskiptakenninguna og röðun fjármögnunarkosta er pví spáð að fyrirtæki með miklar efnislegar eignir séu meira skuldsett. Efnislegar eignir draga úr líkum á umboðsvanda og hrakvali pví eigendur skulda eru betur settir ef lán peirra eru tryggð með veðum (Myers, 2003). Efnislegar eignir draga einnig úr ósamhverfu upplýsinga pví auðveldara er að leggja mat á verðmæti peirra. Efnislegar eignir ættu pví fremur en óefnislegar að stuðla að aukinni skuldsetningu (Frank og Goyal, 2009). Petta staðfesta niðurstöður rannsókna smárra og stórra fyrirtækja (t.d. de Jong, Verbeek, og Verwijmeren, 2011; Frank og Goyal, 2003; Hall ofl., 2004; Michaelas ofl., 1999; Rajan og Zingales, 1995; Shyam-Sunder og Myers, 1999; Sogorb-Mira, 2005). Priðja tilgátan hljóðar pví svo:

\section{T3: Efnislegar eignir hafa jákvæð tengsl við langtímaskuldir og heildarskuldir}

Fórnarskiptakenningin gefur til kynna að arðsöm fyrirtæki noti meiri skuldir í fjármagnsskipan sinni pví að skattahagræði nýtist fremur peim fyrirtækjum sem hafa skattskyldar tekjur. Samkvæmt kenningum um umboðsvanda gagnast skuldir arðbærum fyrirtækjum par sem pau eru líklegri til að hafa mikið sjóðstreymi sem getur freistað stjórnenda (Jensen, 1986). Rannsóknir smárra og stórra fyrirtækja benda pó til pess að arðsöm fyrirtæki fjármagni sig síður með skuldum, en í samræmi við röðun fjármögnunarkosta purfa arðsöm fyrirtæki ekki að nota skuldir til að fjármagna sig pví að pau hafa nægt óráðstafað eigið fé sem er framar í forgangsröðinni (t.d. Fama og French, 2002; Frank og Goyal, 2009; Hall ofl., 2000; Michaelas ofl., 1999; Rajan og Zingales, 1995; Shyam-Sunder og Myers, 1999; Sogorb-Mira, 2005). Fjórða tilgátan er pví:

\section{T4: Arðsemi hefur neikvæð tengsl við langtímaskuldir og heildarskuldir}

Afskriftir dragast frá skattstofni og gætu pví komið í staðinn fyrir skattahagræði skulda. Petta pýðir að fyrirtæki með miklar afskriftir ættu að hafa lægri skuldsetningu (DeAngelo og Masulis, 1980). Hafa sumar rannsóknir sýnt fram á jákvæð tengsl milli afskrifta og skuldsetningar (Harris og Raviv, 1991) en aðrar neikvæð (López-Gracia og Sogorb-Mira, 2008; Sogorb-Mira, 2005) og er í raun óljóst hvort á betur við. Í samræmi við kenningu DeAngelo og Masulis er fimmta tilgátan:

\section{T5: Afskriftir hafa neikvæð tengsl við langtímaskuldir og heildarskuldir}

Rannsóknir hafa sýnt að sveiflur í efnahag hafi áhrif á skuldsetningu og virðast smá fyrirtæki vera viðvæmari fyrir hagsveiflum en stór (Michaelas ofl., 1999). Árin 2005 og 2009 marka upphaf uppsveiflu annars vegar og dýpstu lægð í efnahagslegu tilliti hins vegar og verður fróðlegt að skoða hver staða fyrirtækja var árið 2014. Með pví að skoða pessi mismunandi ár er hugsanlega hægt að draga ályktanir um áhrif sveiflna í efnahag á skuldsetningu fyrirtækja af ólíkri stærð. Sjötta tilgátan er pessi:

T6: Tími hefur áhrif á langtímaskuldir og heildarskuldir 
Pá verða könnuð áhrif pessara breyta á skammtímaskuldir pó svo að sérstakar tilgátur séu ekki settar fram í tengslum við pær. Er petta gert pví að smá fyrirtæki hafa tilhneigingu til að hafa hærra hlutfall skammtímaskulda í fjármagnsskipan sinni (Hughes, 1997).

Aðhvarfsjafnan er pví eftirfarandi (allt bókfærðar tölur):

$y S K U L D S_{i t}=\beta_{1 i}+\beta_{2} \ln E I G N_{i t}-\beta_{3}$ ALDUR $_{i t}+\beta_{4} E_{F N I S L}{ }_{i t}-\beta_{5} A R Đ S E M I_{i t}-\beta_{6} A_{F S K R}$ $+\lambda d t_{-} T I_{M I} I_{1-9}+u i t^{5}$

Að auki er ein opin rannsóknarspurning sett fram: Hvaða áhrif hafði efnahagshrunið á fjárhagslega stöðu ólíkra fyrirtækja á Íslandi?

\section{2 Аðferð}

\subsection{Gagnagrunnur}

Gögn voru fengin frá fyrirtækinu Creditinfo sem sérhæfir sig í miðlun fjárhags- og viðskiptaupplýsinga (Creditinfo, 2015). Gagnagrunnur Creditinfo inniheldur ársreikninga skilaskyldra félaga sem skráð eru hjá ríkisskattstjóra. Í samræmi við lög um ársreikninga nr. 3/2006 eru petta öll hlutafélög, einkahlutafélög, samlagshlutafélög og samvinnufélög. Upprunalegu gögnin fólu í sér lykiltölur úr ársreikningum, ásamt grunnupplýsingum um kennileiti, stofndag, atvinnugrein, ár og uppgjörsmynt. Fyrirtækin voru flokkuð eftir atvinnugrein samkvæmt ÍSAT 2008 flokkunarkerfinu (Hagstofa Íslands, 2015a).

Gögnin voru peim annmörkum háð að prátt fyrir sektarákvæði í lögum skila að jafnaði um 25\% félaga ekki ársreikningi lögum samkvæmt eða um 15\% ef frátalin eru félög sem eru afskráð eða tekin til gjaldprotaskipta á árinu (Atvinnuvega- og nýsköpunarráðuneytið, 2012). Eru vanskil á ársreikningi oftar en ekki undanfari að gjaldproti. Par sem óhófleg skuldsetning getur leitt til gjaldprots kann að vanta í grunninn ársreikninga peirra fyrirtækja sem skuldsettust eru, jafnvel á meðan pau eru enn starfandi. Petta pýðir að brottfall er ekki tilviljanakennt.

Pá var nokkuð um að einstök gildi vantaði, einkum í rekstrarreikning, en sum félög hafa fengið sampykki félagaskrár til að skila samandregnum rekstrarreikningi í samræmi við 116. gr. laga nr. 3/2006 um ársreikninga. Purfa sérstakar samkeppnisaðstæður að mæla með slíkri heimild, en til að skila samandregnum reikningi mega fyrirtækin ekki fara fram úr tveimur af premur stærðarmörkum; 862,5 mkr. eignir, 1.725 mkr. rekstrartekjur og 250 ársverk á reikningsári. Eru fjölmörg fyrirtæki sem nýta sér pessa undanpágu. Svo dæmi sé tekið voru 64,2\% ársreikninga í endanlegu úrtaki með óskráðar rekstrartekjur.

Vegna peirra ástæðna sem nefndar eru hér að ofan var erfitt að greina samfellda rekstrarsögu hjá mörgum fyrirtækjum. Gögnin flokkast pví undir ójafnað margvítt pversnið (unbalanced panel) sem kallar á tilteknar greiningaraðferðir sem komið er að síðar.

\subsection{Framkvæmd}

Grunnurinn nær yfir öll félög á Íslandi sem skiluðu ársreikningi á árunum 2005 til 2014. Áður en úrtak var tekið og gögn hreinsuð voru petta samtals 260.870 ársreikningur fyrir öll árin og að meðaltali 26.087 fyrirtæki ár hvert.

${ }^{5}$ SKULDS = Heildar-, langtíma- eða skammtímaskuldir af heildareignum, lnEIGN = lógaritminn af heildareignum á verðlagi 2014, ALDUR = í árum á uppgjörsári, EFNISL = fastafjármunir /heildar-eignir, ARĐSEMI = EBITDA/heildareignir, AFSKR = afskriftir/heildareignir, dt $=$ dummy breytur fyrir ár 2005 til 2014, $u=$ leifaliðar, $i=$ fyrirtæki, $t=$ tími, $\lambda=$ skurðpunktur tímabreytu. 
Byrjað var á að hreinsa gögnin. Í fyrsta lagi purfti að taka út tvöfaldar færslur. Pær koma til vegna pess að sum félög skila bæði samstæðu- og móðurfélagsreikningi, en notast var við samstæðureikninginn. Í öðru lagi skila fjölmörg fyrirtæki ársreikningi prátt fyrir að starfsemi peirra liggi niðri (óvirk félög). Ef tekið var fram í ársreikningi að engin starfsemi hafi verið á pví ári var færslan tekin út. Í priðja lagi voru teknir út ársreikningar par sem engin gildi voru skráð í rekstrarreikning (eða alls staðar 0) og félög sem höfðu engar tekjur en skiluðu rekstrartapi sem samsvarar útvarpsgjaldi (með öðrum orðum óvirk félög).

Pá purfti að færa gögnin á samanburðarhæft form. Byrjað var á að samræma uppgjörsmynt fyrirtækjanna og var notast við miðgengi Seðlabankans, meðaltal árs, til að umbreyta ársreikningum í krónur (Seðlabanki Íslands, 2015a). Svo var ÍSAT-flokkunin frá árinu 2008 (Hagstofa Íslands, 2015a) aðlöguð pannig að sjávarútvegurinn skipaði sérstakan flokk. Fyrirtæki í vinnslu sjávarafurða voru flokkuð með sjávarútvegi en ekki iðnaði eins og hefðbundið er, líkt og gert var í rannsókn Steins Friðrikssonar (2015). Til að unnt væri að bera saman ársreikninga milli ára voru stærðir uppreiknaðar miðað við vísitölu neysluverðs, meðaltal árs 2014. Að lokum var skilgreining Evrópusambandsins á stærð fyrirtækja (European Commission, 2006) aðlöguð íslenskum aðstæðum:

$>$ Stór fyrirtæki eru félög með 1000 mkr. efnahagsreikning og yfir.

$>$ Meðalstór fyrirtæki eru félög með eignir á bilinu 200 til 999 mkr.

$>$ Smá fyrirtæki eru félög með eignir á bilinu 15 til 199 mkr.

Ekki var talið æskilegt að notast við flokkun Evrópusambandsins óbreytta par sem hún nær ekki fyllilega yfir smæð íslensks atvinnulífs. Samkvæmt henni falla nánast öll íslensk fyrirtæki í flokk lítilla eða örfyrirtækja og var pví ákveðið að stærðarflokka pau með öðrum hætti.

\section{3 Úrtak úr gagnagrunni}

Til að varpa ljósi á fjárhagslega stöðu fyrirtækja hérlendis var tekið úrtak úr gagnagrunninum. Voru ekki tekin með félög sem áttu minna en 15 mkr. eignir til að reyna að útiloka einyrkja og allra minnstu félögin, en starfsmannafjöldi er ekki skráður í gagnagrunninn nema í örfáum tilfellum svo ekki var hægt að byggja á honum. Æskilegt hefði verið að geta tekið einyrkja úr úrtaki, en pau viðmið sem notuð voru útilokuðu ekki félög með verðmætar eignir, en hugsanlega lítinn rekstur í starfsmönnum talið. Í úrtaki voru ekki opinber fyrirtæki, veitur af ýmsum toga, fyrirtæki í landbúnaði 6 og fjármálafyrirtæki. Eftir stóðu, pegar búið var að hreinsa gögnin, félög í níu atvinnugreinum, að meðaltali 8.186 fyrirtæki á ári eða 81.857 ársreikningar í heild. ${ }^{7}$

\subsection{Gerð aðhvarfsgreiningar}

Eins og áður sagði flokkast úrtakið undir ójafnað margvítt pversnið. Eru rannsóknir á fjármagnsskipan fyrirtækja stundum byggðar á slíkum gögnum (Michaelas o.fl., 1998). Til að einfalda úrvinnslu og draga úr hugsanlegum áhrifum brottfalls á aðhvarfsstuðla hafa sambærilegar rannsóknir pó oftar jafnað gögn (balanced panel data) (Shyam-Sunder og Myers, 1999; Frank og Goyal, 2003; Leary og Roberts, 2010). Felur úrtak pá eingöngu í sér pau fyrirtæki

${ }^{6}$ Atvinnugreinar par sem umsvif hins opinbera eru mikil.

7 Ítarlegri umfjöllun og niðurbrot á atvinnugreinar má finna í MS ritgerð Önnu Rutar Práinsdóttur (http://hdl.handle.net/1946/23459). Tekið skal fram að gögn frá árinu 2014 voru pá ekki aðgengileg og niðurstöður pví ekki að öllu leyti sambærilegar. 
sem skila ársreikningum öll árin en auk pess eru fyrirtæki felld út ef gildi vantar í ársreikning. Jafnað úrtak er pví ekki handahófskennt og dregur pað umtalsvert úr alhæfingargildi pessara rannsókna yfir á pýði. Ekki er hægt að fullyrða að niðurstöður eigi við um ung fyrirtæki og pau sem lent hafa í fjárhagserfiðleikum, par sem vanskil á ársreikningi eru oftar en ekki undanfari að gjaldproti eins og áður kom fram. Var pví ákveðið að takmarka ekki gögnin og notast við ójöfnuð gögn. Aðhvarfsgreining með bundnum áhrifum eða FEM (fixed-effect model) ræður við úrvinnslu slíkra gagna (Wooldrige, 2013). Í FEM er leyfð fylgni milli frumbreyta og peirra ómældu eiginleika fyrirtækja sem breytast ekki yfir tíma $\left(\varepsilon_{i}\right)$ og er gert ráð fyrir að hvert fyrirtæki hafi sinn eigin skurðpunkt sem gleypir pessi áhrif (Gujarati og Porter, 2009; Wooldridge, 2013). Slík greining skýrir pví áhrif frumbreyta á breytileika innan hvers fyrirtækis yfir tíma.

Við gerð aðhvarfsgreininga með ójöfnuðu margvíðu pversniði er ýmislegt annað sem hafa parf í huga. Greina parf hvort marglínuleiki (multicollinearity) sé til staðar í gögnum. Er hægt að nema раð með VIF (variance-inflating factor), sem sýnir hvernig dreifni skýribreytu eykst pegar marglínuleiki er til staðar. Einnig er hægt að kanna fylgni milli frumbreyta (Gujarati og Porter, 2009). Eiginfylgni (autocorrelation) er mjög algeng í tímaraðargögnum og getur skekkt stuðla í aðhvarfsgreiningu. Pá geta útlagar og slembnar hallatölur fyrirtækja valdið misdreifni (heteroscedasticity) sem skekkir einnig aðhvarfsstuðla. Misdreifni og sjálffylgni brjóta forsendur aðhvarfsgreiningar og draga réttmæti greiningarinnar og tölfræðileg próf í efa. Hægt er að prófa hvort misdreifni og eiginfylgni sé til staðar með Breusch-Pagan eða White prófi og leiðrétta fyrir með pví að gera greininguna HAC (heteroskedasticity and autocorrelation consistent). Er pá ákveðnum aðferðum beitt til að draga úr misdreifni og eiginfylgni sem gerir fræðimönnum kleift að draga ályktanir eins og ef um enga væri að ræða (Gujarati og Porter, 2009).

\section{Niðurstöður}

Við útreikninga á meðaltölum eftir árum var ávallt notast við samanlagðar tölur fyrirtækja í úrtaki. Til dæmis var rekstrarhagnaði allra fyrirtækja af ákveðinni stærð deilt með fjölda fyrirtækja í viðkomandi stærðarflokki eftir árum. Stór fyrirtæki vega pví pyngra í meðaltölum. Hlutföll svo sem eiginfjárhlutfall og aðrar kennitölur voru reiknuð með sama hætti, pað er með pví að nota samtölur í útreikninga.

\subsection{Fjárhagsleg staða og fjármagnsskipan fyrirtækja}

\subsubsection{Lýsandi mynd af fyrirtækjum í úrtaki}

Heildarfjöldi fyrirtækja í úrtaki jókst um 22,8\% frá upphafsári til lokaárs. Mest var aukningin árin fyrir hrun pegar aðgengi að lánsfjármagni var meira, en svo varð fækkun eins og við var að búast árin 2008-2010, bæði vegna aukinnar tíðni gjaldprota og færri nýskráninga (Hagstofa Íslands, 2015c).

Mynd 1 sýnir hlutfallslega breytingu á fjölda fyrirtækja í úrtaki frá fyrra ári eftir stærð peirra. Árin 2006 og 2007 fjölgaði stórum fyrirtækjum hlutfallslega mest frá fyrra ári, en árin 
2008-2012 varð fækkun fyrirtækja í pessum stærðarflokki. Pá varð einnig mikil fjölgun í hópi

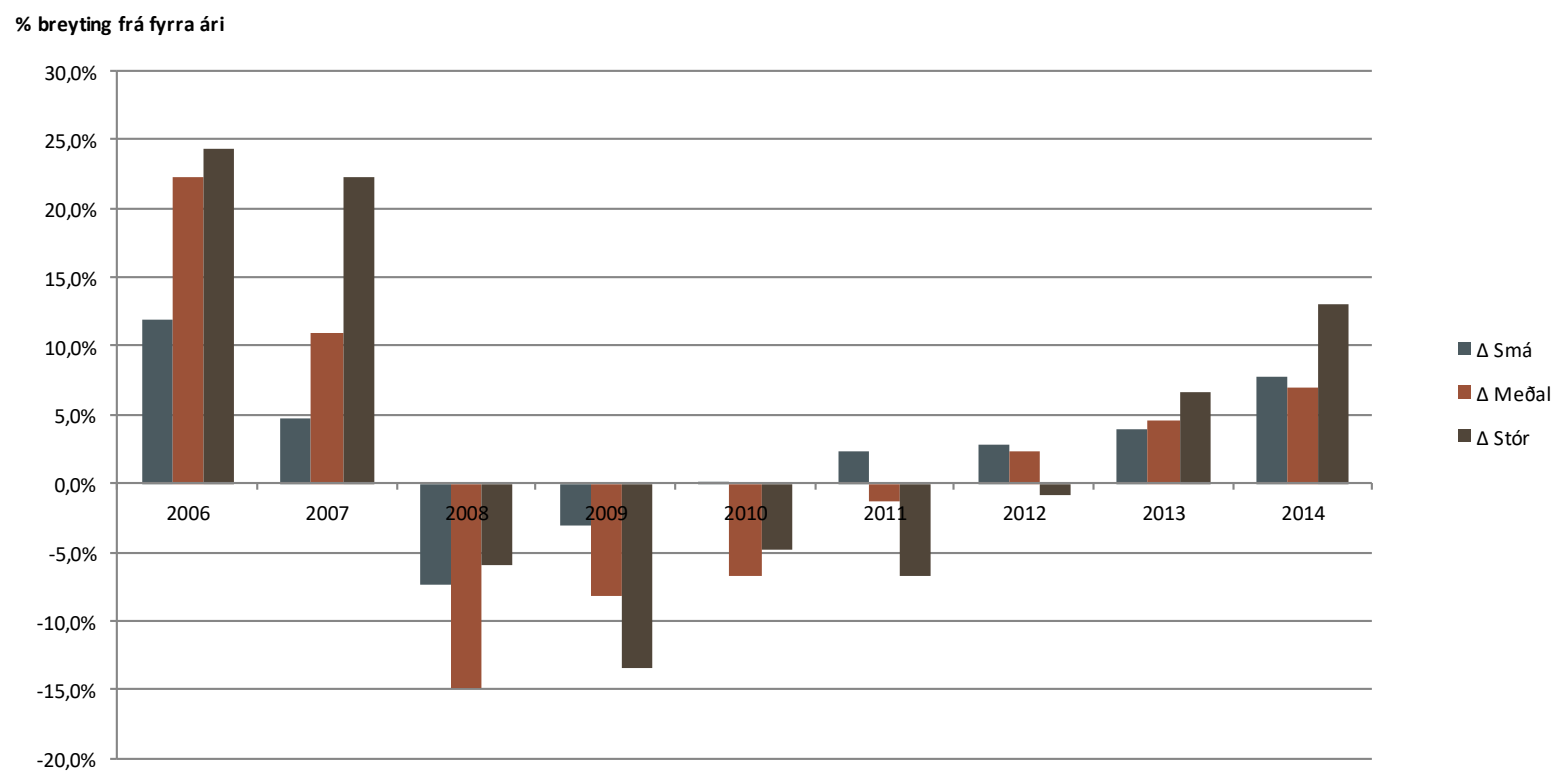

Mynd 1. Hlutfallsleg breyting á fjölda fyrirtækja í úrtaki frá fyrra ári, greint eftir stærðarflokkum.

meðalstórra fyrirtækja milli áranna 2005-2007, en svo fækkun árin 2008-2011. Hafa ber í huga að myndin sýnir ekki eingöngu gjaldprot og nýskráningar, heldur færast fyrirtæki milli stærðarflokka ef breytingar verða á stærð efnahagsreiknings. Fækkunin kann pví að stafa af pví að virði eigna dregst saman, auk pess sem sameiningar fyrirtækja í sama stærðarflokki draga úr fjölda peirra. Flest ár voru breytingar minnstar milli ára í hópi smárra fyrirtækja.

Meiri hluti fyrirtækja í úrtaki voru smá, eða að meðaltali 79,6\% félaga öll árin. Sem hlutfall af samanlögðum eignum fyrirtækja í úrtaki námu eignir peirra pó einungis 6,1\% að meðaltali. Meðalstóru fyrirtækin voru $14,4 \%$ af fjölda og nam hlutfall eigna af samanlögðum eignum $8,3 \%$ að meðaltali. Stærstu fyrirtækin, sem áttu hlutfallslega mest eða 85,6\% af eignum, voru ekki nema 6,0\% af fjölda í úrtaki að meðaltali. Lítil frávik hafa verið á pessum hlutföllum yfir tíma, pótt greina megi að dregið hafi úr hlut smárra fyrirtækja árin fyrir efnahagskreppu, bæði sem hlutfall af fjölda og eignum. Peim fjölgaði pó á pessum tíma, pannig að samdráttur stafar líklega fremur af hlutfallslegri fjölgun stærri fyrirtækja.

\subsubsection{Rekstrarreikningur}

Heilt yfir hafa meðalrekstrartekjur og -hagnaður fyrirtækja á verðlagi 2014 vaxið á pessum árum en bil milli atvinnugreina hefur aukist frá efnahagshruni. Almennt má segja að meðalrekstrarafkoma fyrirtækja í útflutningsgreinum svo sem sjávarútvegi og iðnaði hefur vaxið frá árinu 2005 á meðan meðalrekstrarhagnaður atvinnugreina sem anna fyrst og fremst innlendri eftirspurn, svo sem fyrirtækja í byggingarstarfsemi og mannvirkjagerð, verslun, upplýsinga- og fjarskiptageira, og sérfræðiráđgjöf og sérhæfðri pjónustu hefur dregist saman. Fasteignageirinn hefur tekið vel við sér eftir efnahagshrun og sömuleiðis rekstrarafkoma peirra atvinnugreina sem notið hafa góðs af lágu gengi íslensku krónunnar svo sem samgöngur og flutningar, og hótel og veitingarekstur. Niðurstöður gefa vísbendingu um að gengislækkun krónunnar hafi bætt samkeppnisstöðu útflutningsfyrirtækja á erlendum mörkuðum, auk pess sem rekstrartekjur jukust í krónum talið fyrir sömu fjárhæð í erlendri mynt. 
Samkvæmt niðurstöðum eru tæplega 70\% fyrirtækja með jákvæða rekstrarafkomu á tímabilinu, en til að varpa ljósi á áhrif efnahagshrunsins á meðalrekstrarhagnað er einnig mjög fróðlegt að greina hlutfall fyrirtækja sem skila rekstrartapi pessi ár. Að jafnaði skila smá félög (i 31,9\% tilvika) oftar rekstrartapi en meðalstór $(28,1 \%)$ og stór $(24,2 \%)$, prátt fyrir að á milli áranna 2007 og 2009 hafi hlutfall stórra fyrirtækja með neikvætt EBIT aukist um níu

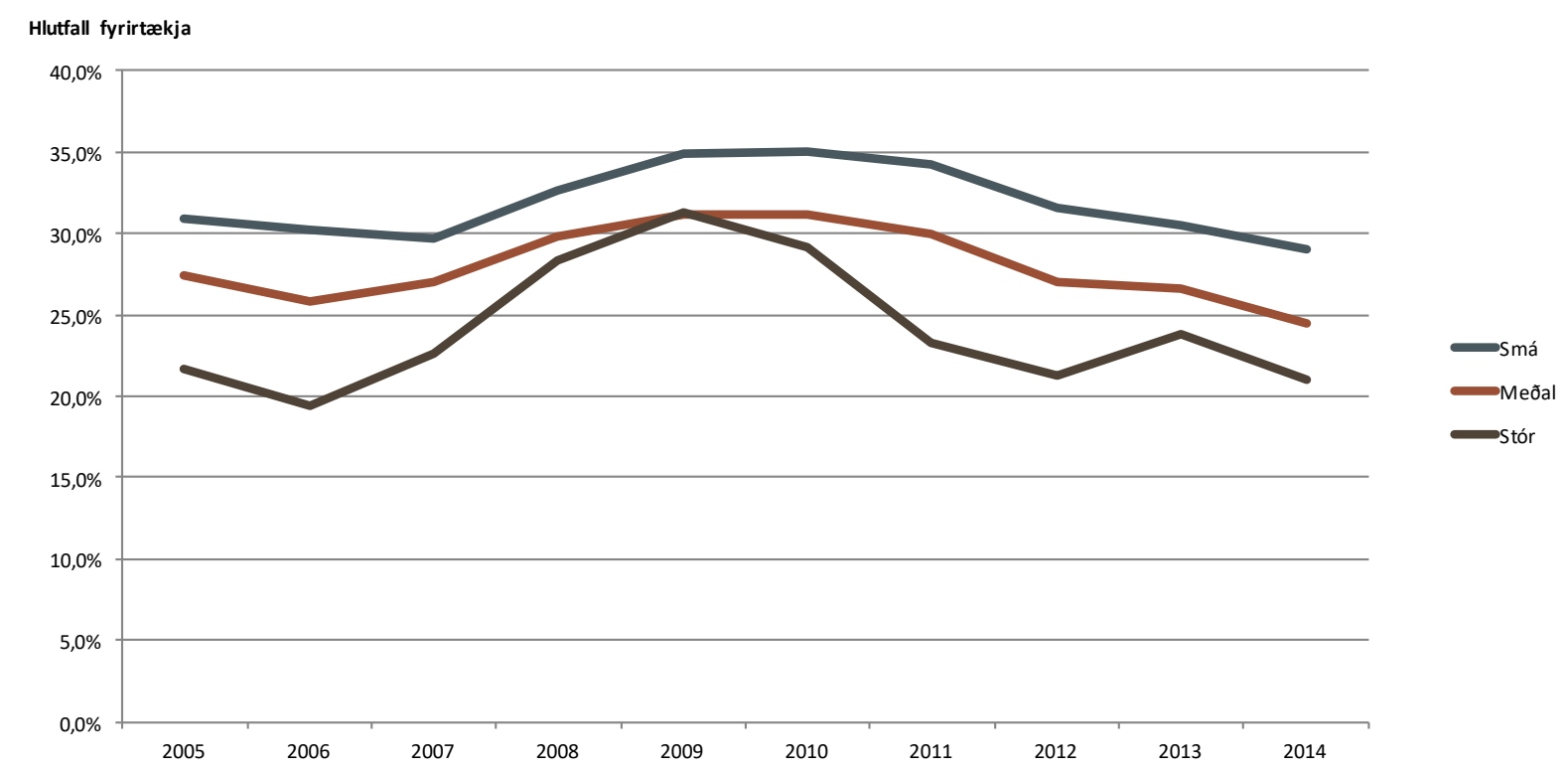

prósentustig (sjá mynd 2). Árið 2014 dró úr hlutfalli fyrirtækja með neikvæða afkomu og var hlutfallið orðið lægra en árin fyrir efnahagshrun, að minnsta kosti í hópi eignaminni fyrirtækjanna.

Mynd 2. Hlutfall fyrirtækja með neikvæða rekstrarafkomu árin 2005-2014, greint eftir stærðarflokkum.

\subsubsection{Efnahagsreikningur}

Mynd 3 sýnir próun eigna og skulda á verðlagi ársins 2014 og breytingar á eiginfjárhlutfalli fyrirtækja í úrtaki árin 2005-2014. Sjá má hvernig efnahagsreikningar fyrirtækja bólgnuðu út árin fyrir efnahagshrunið og hvernig jafnvægi eigna og skulda raskaðist með peim afleiðingum að eiginfjárhlutfall snarlækkaði árið 2008 er skuldsetning hélt áfram að aukast en virði eigna dróst saman. Fram kemur í rannsókn Steins Friðrikssonar (2015) á skuldsetningu 500 stærstu fyrirtækja landsins að árin 2000-2003 hafi ríkt ágætt jafnvægi milli eigna og skulda. Víxlverkandi áhrif aukinnar skuldsetningar og hækkandi eignaverðs í aðdraganda hrunsins gerðu fyrirtækjum kleift að skuldsetja sig í auknum mæli par sem eignir hækkuðu í virði. Auk pess átti innflæði erlends fjármagns pátt í stækkun efnahagsreikninga fyrirtækja á pessum árum (Steinn Friðriksson, 2015). Sýna niðurstöður hvernig samanlögð eign fyrirtækja lækkaði árið 2008 um 12,5\% frá árinu áður, á meðan samanlagðar skuldir jukust um 11,3\% milli ára (sjá mynd 3). Sést einnig að skuldaaukning árin 2008 og 2009 var aðallega í formi langtímaskulda sem eru að öllum líkindum vaxtaberandi. Hlutfall gengistryggðra skulda við bankakerfið var í lok árs 2009 um 70\% (Viðskiptaráð Íslands, 2010). Líklega má pví að töluverðu leyti rekja aukna skuldsetningu fyrirtækja árin 2008 og 2009 til gengistryggðra eða verðtryggðra lána, en gengi krónunnar lækkaði um nálægt helming gagnvart viðskiptaveginni gengisvísitölu við fall bankanna auk pess sem verðlag hækkaði um 18,6\% á árinu 2008.

Pá má sjá hvernig skuldir sem hlutfall af eignum drógust saman síðustu árin í úrtaki og hvernig eiginfjárhlutfall hækkaði aftur í 36,2\% að meðaltali árið 2013 og hélst svo stöðugt í 
36,0\% árið eftir. Pessi ár unnu íslensk fyrirtæki markvisst að pví að greiða niður skuldir auk pess sem fjármálastofnanir komu að endurskipulagningu efnahagsreikninga með afskriftum skulda eða niðurfærslu til samræmis við rekstrar- eða eignavirði fyrirtækjanna og greiðslugetu peirra. Í einhverjum tilvikum var skuldum breytt í eigið fé en verst settu fyrirtækjunum var slitið (Steinn Friðriksson, 2015; Pórólfur Mattíasson, 2012). Pessar aðgerðir leiddu til pess að samanlagðar skuldir fyrirtækja urðu 33,4\% lægri árið 2014 en pegar mest var árið 2009, sem gerði pað einnig að verkum að eiginfjárstaða fyrirtækjanna varð jafnvel betri en hún var árið 2005, sérstaklega peirra stærstu.

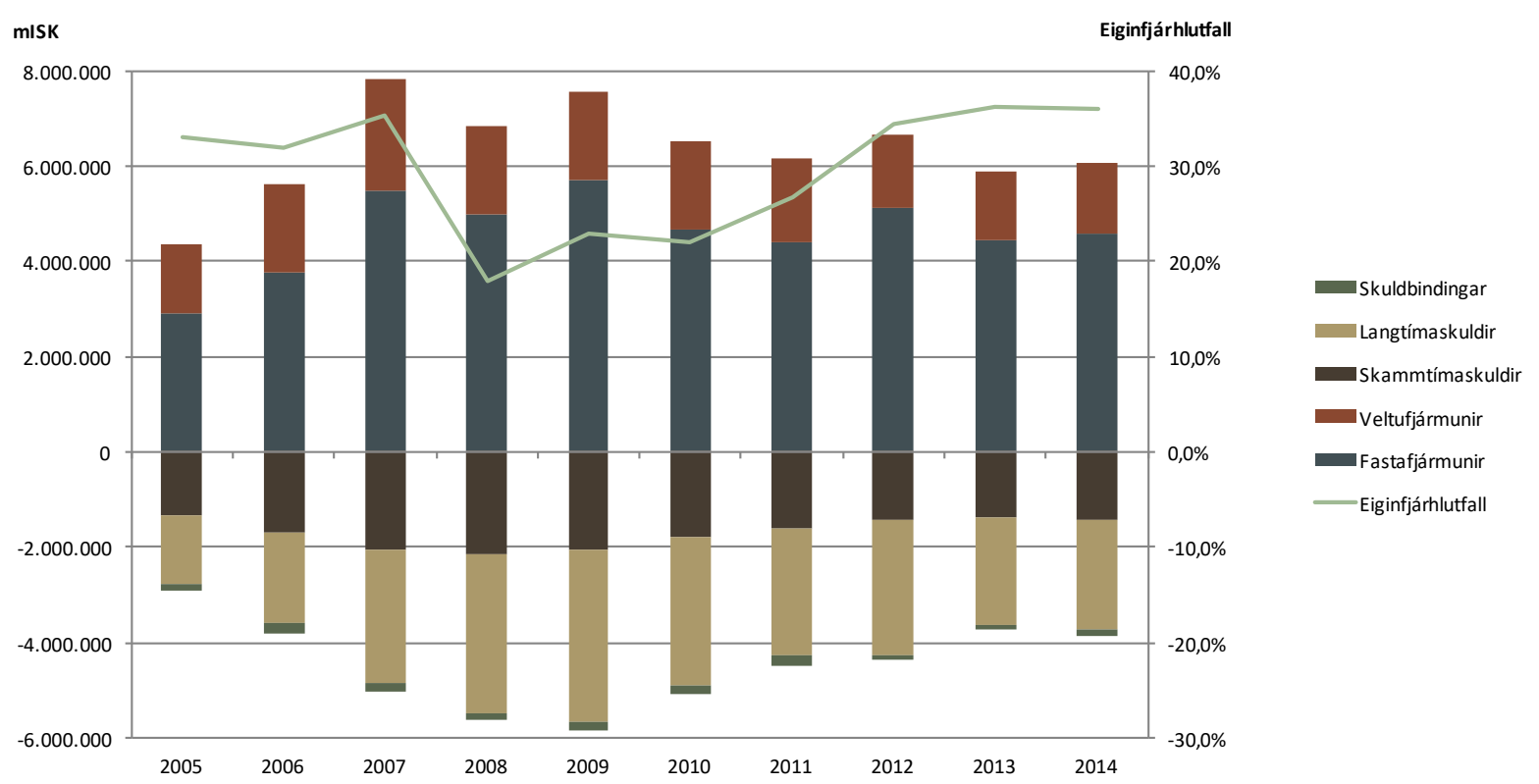

Mynd 3. Próun efnahagsreiknings ásamt eiginfjárhlutfalli á verðlagi 2014.

Fróðlegt er að greina breytingar á hreinum skuldum milli ára og má lesa úr peim áherslur lánastofnana árin í úrtaki (sjá mynd 4). Milli áranna 2005 og 2006 jukust hreinar skuldir meðalstórra og stórra fyrirtækja yfir 35\% en hreinar skuldir smárra fyrirtækja ekki nema um 9,8\%. Milli áranna 2006 og 2007 var áhersla lögð á eignamestu fyrirtækin og varð breyting á hreinum skuldum 49,2\% á meðan smá og meðalstór máttu una við rúmlega 3\% vöxt. Frá árinu 2007 til ársins 2008 jukust hreinar skuldir að meðaltali um 50\% milli ára. Árin 2010-2014 var svo verulegur samdráttur (nema árin 2012 og 2014 hjá stórum og 2013 hjá smáum) en árið 2013 var endurskipulagningu fyrirtækja og leiðréttingu ólögmætra lánasamninga lánastofnana að mestu lokið (Samkeppniseftirlitið, 2013) auk pess sem fyrrgreindar aðgerðir höfðu væntanlega skilað árangri (sjá mynd 4). Í alpjóðlegum samanburði voru hreinar skuldir pó enn fremur háar. Sem dæmi voru hreinar skuldir stærri fyrirtækja á Íslandi í hlutfalli við EBITDA að jafnaði um tvöfalt meiri en skráðra evrópskra fyrirtækja árið 2011 (Samkeppniseftirlitið, 2012).

Ef skuldsetning er skoðuð nánar eftir stærð fyrirtækja, kemur í ljós að stór fyrirtæki hafa hærra hlutfall langtímaskulda en smá og meðalstór félög, sem virðast frekar fjármagna sig með

8 Um 80\% lánsfjármögnunar innlendra fyrirtækja er frá fjármálastofnunum (Steinn Friðriksson, 2015). 
skammtímaskuldum9. Petta kemur ekki á óvart par sem stór félög hafa einnig hærra hlutfall veðhæfra eigna (fastafjármuna) af heildareignum en smá og meðalstór fyrirtæki sem eykur aðgengi að langtímaskuldum. Er sú niðurstaða að minni félög hafi lægra hlutfall Hlutfallsleg breyting

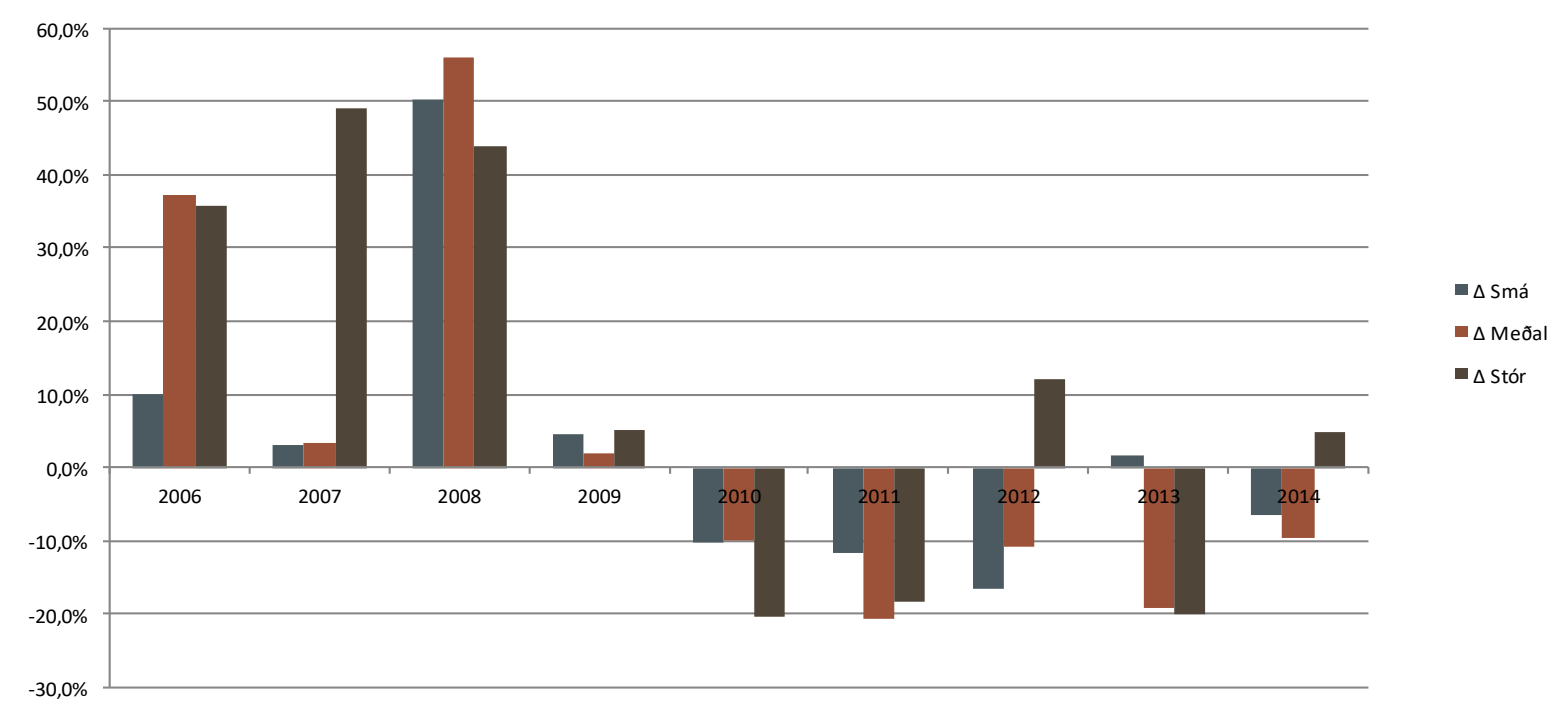

Mynd 4. Hlutfallsleg breyting hreinna skulda frá fyrra ári, greint eftir stærðarflokkum fyrirtækja.



Mynd 5. Hlutfall fyrirtækja með neikvætt eigið fé árin 2005-2014, greint eftir stærðarflokkum.

veðhæfra eigna og hærra hlutfall skammtímaskulda í fjármagnsskipan í samræmi við niðurstöður rannsókna (Hughes, 1997).

${ }^{9}$ Skammtímaskuldir geta bæði verið vaxtaberandi og ekki (til dæmis yfirdráttarheimildir annars vegar og viðskiptaskuldir hins vegar) svo erfitt er að segja nákvæmlega til um áhrif pess á fjárhagslega stöðu og gjaldfærni smárra fyrirtækja í samanburði við stór nema greina pað sérstaklega. Skuldaaukning smárra og meðalstórra félaga árið 2008, eins og stórra, stafaði pó að mestu leyti af hækkun langtímaskulda. 
Athygli vekur hversu algengt er að félög hafi neikvætt eigið fé, en árið 2008 voru pau um $45 \%$ af fyrirtækjum í úrtaki (sjá mynd 5). Öll árin er neikvætt eigið fé hlutfallslega algengara hjá smáum og meðalstórum félögum en stórum, prátt fyrir að árið 2008 hafi peim fyrirtækjum af öllum stærðum fjölgað gríðarlega sem skiluðu neikvæðu eigin fé. Líklegt er að sú próun hafi að miklu leyti stafað af aukinni skuldsetningu vegna gengislækkunar og verðbólgu í kjölfar fjármálaáfallsins eins og áður kom fram, en auknar lántökur komu par væntanlega einnig við sögu. Yfirskuldsettum félögum ${ }^{10}$ fjölgaði umtalsvert milli áranna 2007 og 2008, stórum fyrirtækjum mest eða um 32 prósentustig, meðalstórum um 23 og smáum um 12 prósentustig. Segja má að hlutfall fyrirtækja með neikvætt eigið fé hafi haldist nokkuð hátt til ársins 2010, pegar pað tók að færast í fyrra horf (sjá mynd 5).

Fjölgun fyrirtækja sem skila rekstrarhagnaði prátt fyrir að vera með neikvætt eigið fé gefur einnig til kynna að hlutfallsleg fjölgun yfirskuldsettra fyrirtækja eigi að miklu leyti rætur að rekja til ytri aðstæðna. Að jafnaði skila tæplega 53\% fyrirtækja með neikvætt eigið fé hagnaði árin 2005-2014. Árið 2008 voru mun fleiri fyrirtæki með lífvænlegan rekstur en árið áður (um $60 \%$ ), en voru pó tæknilega gjaldprota. Með öðrum orðum, pótt fyrirtækjum með neikvætt eigið fé hafi fjölgað, voru pau betur stæð rekstrarlega séð.

\subsection{Samanburður á kennitölum, próun milli ára}

Pegar bornar eru saman algengar kennitölur milli ára er mjög mikilvægt að hafa í huga að ólík viðmið geta átt við í mismunandi atvinnugreinum og fyrir ólíka starfsemi fyrirtækja. Er pví eðlilegt að kennitölur komi misvel út fyrir ólíkan rekstur. Umfjöllunin er hér takmörkuð við algild viðmið og er greint frá próun milli ára. Í viðauka má sjá nánari skilgreiningar á pví hvernig kennitölur voru reiknaðar og viðmið.

\subsubsection{Skuldsetning (vogun)}

Skuldsetningu er ætlað að mæla hlutfall skulda í fjármagnsskipan fyrirtækja og hættu á greiðslufalli til langs tíma. Er erfitt að setja algilt viðmið um pað sem telst eðlilegt hlutfall skulda og eigin fjár og eru kennitölur meðal annars háðar hlutfalli veltu- og fastafjármuna og stöðugleika tekna. Ásættanleg skuldsetning er pví mishá eftir atvinnugreinum og stærð fyrirtækja. Almennt má pó segja að hátt hlutfall skulda, sér í lagi við erfiðar ytri aðstæður svo sem hátt verðbólgustig og miklar gengissveiflur, auki hættu á pví að fyrirtæki verði bæði ógjaldfær samkvæmt efnahagsreikningi og að pau ráði ekki við greiðslubyrði pegar að gjalddaga kemur. Teljast fyrirtæki ógjaldfær ef öðrum hvorum mælikvarðanum er ekki fullnægt (Seðlabanki Íslands, 2011a). Pá er fyrirtækjum skylt samkvæmt lögum nr. 21/1991 um gjaldprotaskipti o.fl. að gefa bú sitt upp til gjaldprotaskipta ef pau geta ekki staðið í skilum pegar kröfur falla í gjalddaga og ef ekki er talið líklegt að greiðsluörðugleikar muni líða hjá innan skamms (2. mgr. 64. gr.).

Gríðarlegar breytingar urðu á fjármagnsskipan fyrirtækja árið 2008. Til dæmis urðu skuldir rúmlega 4,5 sinnum eigið fé, en kennitölur færðust smám saman í fyrra horf eftir árið 2010 og gáfu vísbendingu um batnandi stöðu pótt halda megi fram að skuldsetning hafi enn verið of há árið 2013 samkvæmt viðmiðum¹1. Fróðlegt hefði verið að greina fleiri ár aftur í

${ }^{10}$ Hér er átt við fyrirtæki með neikvætt eigið fé, sem eru tæknilega gjaldprota.

${ }^{11}$ Með pví að nota samtölur í útreikninga eykst vægi stórra fyrirtækja í meðaltölum. Ef hvert og eitt fyrirtæki er jafnt vegið, pað er ef meðaltöl eru byggð á útreiknuðum hlutföllum fyrir hvert og eitt fyrirtæki, verður fjárhagsleg staða önnur (smá fyrirtæki eru fleiri í úrtaki) og í raun mun verri. Til dæmis var eiginfjárhlutfall fyrirtækja árið 2014 ekki nema 15,5\% að meðaltali með peirri aðferð. 
tímann, en svo virðist sem íslensk fyrirtæki reiði sig í of miklum mæli á skuldir við fjármögnun eigna sinna.

Ef fyrirtækjum er skipt eftir stærð sést að skuldahlutfall stóru fyrirtækjanna hefur að meðaltali verið um og yfir pví sem æskilegt pykir, en lítil og meðalstór eru umtalsvert meira skuldsett (sjá mynd 6). Er pað öfugt bæði við kenningar og niðurstöður rannsókna sem fjallað var um í upphafi sem sýna að stærð fyrirtækja fer saman við aukna skuldsetningu. Sjá má á mynd 6 hvernig eiginfjárstaða smárra og meðalstórra fyrirtækja varð að meðaltali neikvæð árin 2008-2010, pegar hlutfall skulda og eigna fór yfir 1. Voru pessi fyrirtæki mjög voguð í aðdraganda fjármálaáfallsins og pví versnaði staða peirra jafnvel enn meira en hinna stóru.

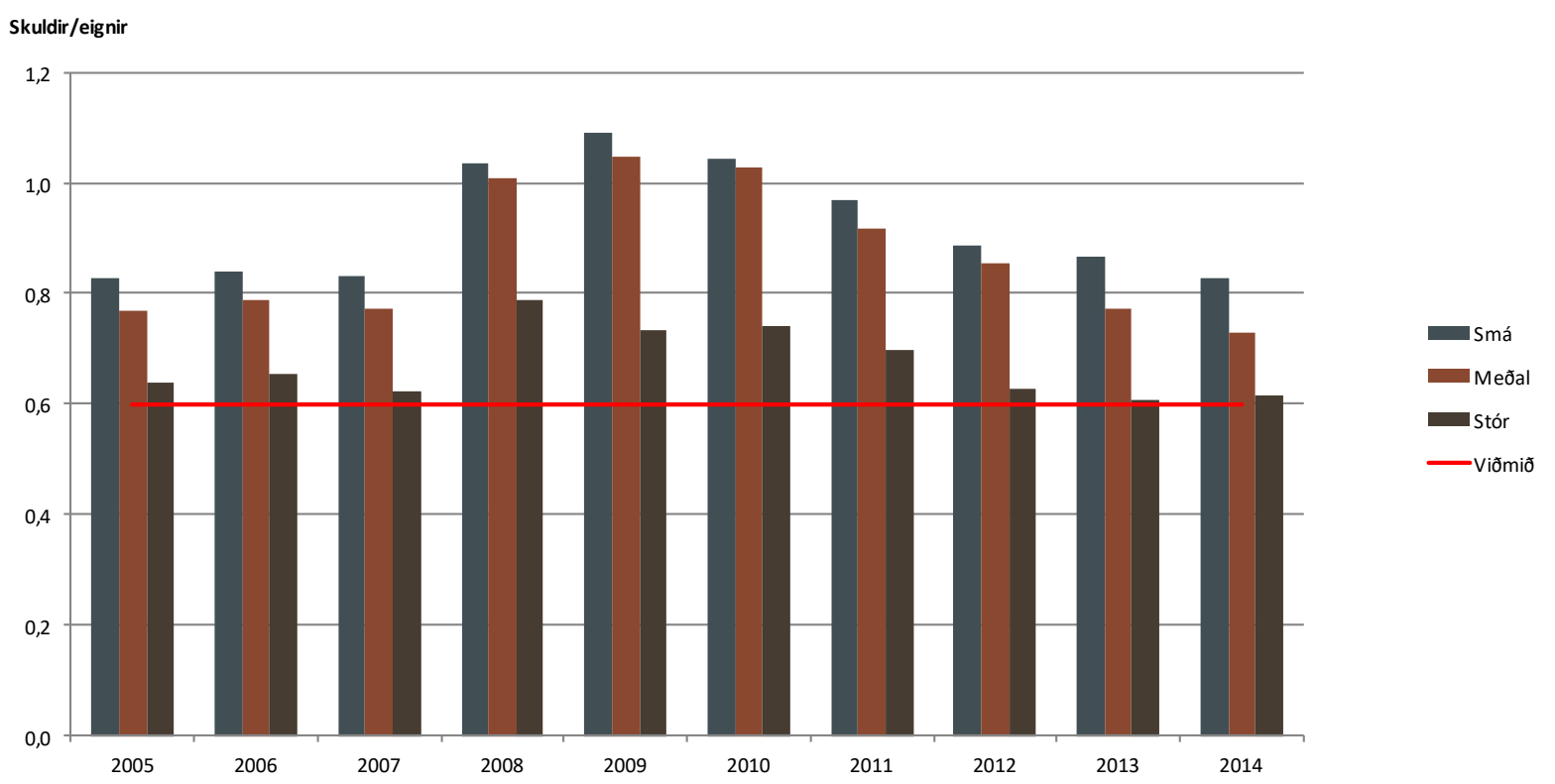

Mynd 6. Skuldahlutfall fyrirtækja árin 2005-2014, greint eftir stærðarflokkum.

Eflaust eru margar ástæður fyrir pessari skuldaaukningu, en til viðbótar við hækkun skuldsetningar vegna gengislækkunar krónunnar og aukinnar verðbólgu, dró verðbólgan eins og fram hefur komið verulega úr innlendri eftirspurn. Svigrúm smárra og meðalstórra fyrirtækja til að mæta áfalli sem pessu með útgáfu hlutafjár er mun takmarkaðra en stórra, par sem ekki er virkur markaður með óskráð bréf og skráning kostnaðarsöm. Pví er líklegt að eina leiðin fyrir smá og meðalstór fyrirtæki til að fjármagna sig á pessum tíma hafi verið að auka lántöku. Kemur pað heim og saman við niðurstöður skýrslu Viðskiptaráðs frá árinu 2009 um að litlum og meðalstórum fyrirtækjum á pessum tíma hafi eingöngu staðið til boða að fjármagna sig með lántökum og fyrirgreiðslum í bönkum á háum vöxtum. Takmarkað aðgengi að fjármögnun á pessum tíma snerist pví líkast til að mestu um vaxtakjör (Viðskiptaráð Íslands, 2009). En aðgengi stórra fyrirtækja að fjármagni var einnig takmarkað á pessum tíma, pví jafnvel pótt geta peirra til að gefa út hlutafé sé meiri en smárra var vilji til að fjárfesta lítill. Nafnvextir á áhættulausum innlánsreikningum voru mjög háir fram á mitt ár 2009 og líklegri til að bera örugga ávöxtun. Allt til ársins 2013 lá markaður með fyrirtækjaskuldabréf með örfáum undantekningum niðri og pví sennilegt að skömmu eftir hrun hafi einu fjármögnunarmöguleikar margra stórra fyrirtækja einnig verið fólgnir í lántökum hjá fjármálastofnunum. Samningsstaða peirra var pó eflaust betri og fjármagnskostnaður par af leiðandi lægri. Auk pess má gefa sér að stór fyrirtæki hafi oftar en smá verið varin fyrir gengisáhrifum, sem hefur líklega mildað sveifluna hjá peim að einhverju leyti. Í samræmi við 
niðurstöður rannsókna Michaelas ofl. (1999) og Damijan (2014) voru smá félög á Íslandi pví viðkvæmari fyrir efnahagslegum sveiflum en stór.

Ef próun skulda á föstu verðlagi 2014 er skoðuð, sést að aukning langtímaskulda milli áranna 2007 og 2008 var 36,7\% hjá smáum fyrirtækjum, 34,1\% hjá meðalstórum og 17,1\% hjá stórum. Á sama tíma lækkuðu skammtímaskuldir smárra fyrirtækja um 0,3\%, meðalstórra um 6,7\% en 7,6\% hækkun mældist hjá stórum. Alla aukningu heildarskulda smárra og meðalstórra fyrirtækja mátti pví rekja til langtímaskulda (og meira til 103,1\% og 142,4\%), en aðeins 88,7\% hjá stórum. Pessi langtímaskuldaaukning kemur heim og saman við breytingar á hlutfalli langtímaskulda og fjármagns en hún er ekki í samræmi við niðurstöður rannsókna Proenca, Laureano og Laureano (2014) sem sýndu fram á aukna notkun skammtímaskulda við fjármögnun smárra fyrirtækja í efnahagshruninu.

\subsubsection{Greiðsluhæfi}

Með pví að bera saman fjárhagslegar skuldbindingar við afkomu áður en tekið er tillit til vaxtagreiðslna og vaxtatekna, skattgreiðslna og afskrifta (EBITDA) er hægt að meta getu fyrirtækja til að standa undir greiðslu skulda með hagnaði frá rekstri án fjármögnunarkostnaðar og annarra fjármagnsliða. Lágt gildi gefur til kynna að félög hafi næga sjóði til að mæta afborgunum, en hátt gildi að pau muni ekki ráða við greiðslubyrði á gjalddaga. Er gildið 3 pað viðmið sem oftast er notað pegar talað er um eðlilegt hlutfall. Talið er óásættanlegt að pað fari mikið yfir 4-5 par sem pað bendir til pess að EBITDA standi ekki undir skuldbindingum og líkur á greiðslufalli aukast. Eins geta fyrirtæki lent í erfiðleikum við að gefa út nýjar skuldir til að nýta sér fjárfestingakosti í framtíðinni (sjá t.d. Damijan, 2014).

Niðurstöðurnar gefa afar áhugaverða sýn á íslensk fyrirtæki fyrir, í og eftir efnahagshrun. Mynd 7 sýnir hlutfall skulda og EBITDA fyrirtækja af mismunandi stærð. Í

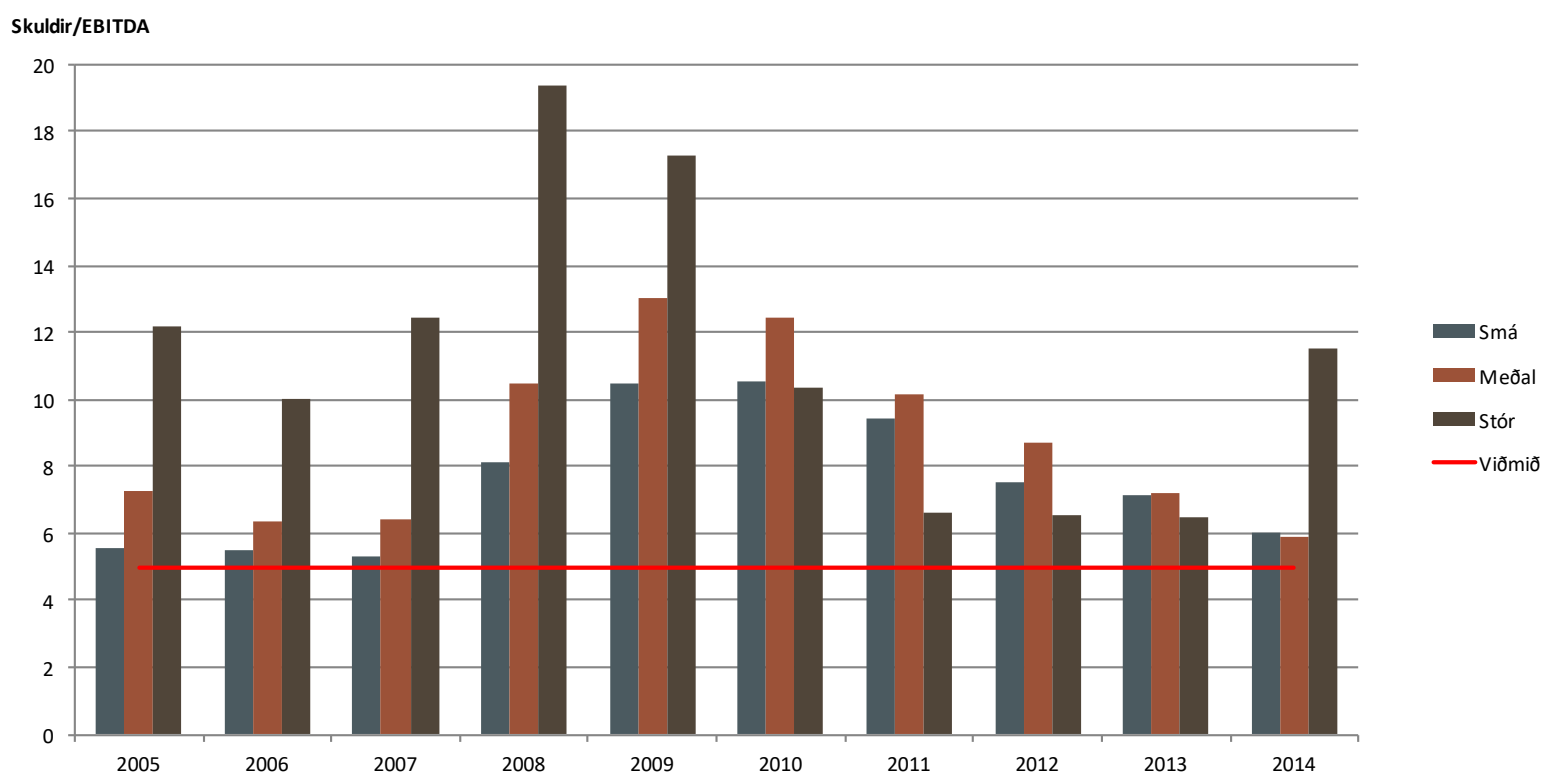

Mynd 7. Greiðsluhæfi fyrirtækja árin 2005-2014, miðað við hlutfall skulda og EBITDA, greint eftir stærðarflokkum.

fyrsta lagi er athyglisvert að sjá að íslensk fyrirtæki af mismunandi stærð ná að meðaltali ekki að uppfylla viðmið um ásættanlegt hlutfall skulda og EBITDA neitt ár í úrtaki. Í öðru lagi vekur athygli að fyrstu fimm árin er greiðsluhæfi smærri fyrirtækja samkvæmt pessum mælikvarða mun betra en stærri, pótt staða eignamestu fyrirtækjanna ætti eftir að breytast til 
batnaðar árin 2010-2013. Gæti pað verið vísbending um að eignameiri fyrirtækin hafi náð að vinna úr fjármálaáfallinu á skemmri tíma en hin eignaminni. Árið 2014 fer greiðsluhæfi eignamestu fyrirtækjanna svo að líkjast pví sem tíðkaðist árin fyrir efnahagshrun, en skuldir voru pá 11,5 sinnum EBITDA. Fram kemur í rannsókn Steins Friðrikssonar (2015) á 500 stærstu fyrirtækjunum að petta hlutfall hefur alla jafna verið um og yfir 7 hér á landi, sem er áhyggjuefni ef horft er til aukinnar gjaldprotatíðni slíkra fyrirtækja. Pað er pó umtalsvert lægra en fram kom hér, en árið 2011 fór greiðsluhæfi stórra fyrirtækja í fyrsta sinn undir 10. Hvort heldur sem er, verður ekki hjá pví komist að velta peirri spurningu upp hvort fyrirtæki á Íslandi séu að jafnaði ekki greiðsluhæf eins og meðaltöl gefa til kynna.

Sömu sögu má segja ef greiðsluhæfi er mælt með veltufjárhlutfalli eða reiðufjárhlutfalli. Veltufjárhlutfall mælir getu fyrirtækja til að standa undir skuldbindingum næstu 12 mánaða. Er almennt talað um að gildið 2 sé ásættanlegt fyrir flestan rekstur pótt pað kunni að vera misjafnt milli atvinnugreina, en að pað ætti ekki að fara niður fyrir 1,2. Próun veltufjárhlutfalls yfir tíma gefur pó skýrari mynd en gildin sem slík (Petersen og Plenborg, 2012; Walsh, 2002; Weygandt, 2002). Samkvæmt niðurstöðum nær meðalveltufjárhlutfall íslenskra fyrirtækja aldrei 2 og er undir 1 flest árin í úrtaki (sjá mynd 8). Er pað sterk vísbending um að fyrirtæki hafi sögulega átt í erfiðleikum par sem veltufjármunir duga að meðaltali ekki fyrir skammtímaskuldum. Reiðufjárhlutfall er mun strangari mælikvarði og er miðað við að nægjanlegt hlutfall sé á bilinu 0,2-0,4 (Weygandt, 2002).

Veltufjárhlutfall gefur aðeins betri mynd af eignameiri fyrirtækjunum en peim eignaminni, en einungis árin 2008 og 2009 fór hlutfall peirra undir 1 (sjá mynd 8). Sömuleiðis er reiðufjárhlutfall peirra fremur gott í samanburði eða að meðaltali 0,23 frá árinu 2009. Er próun eignaminnstu fyrirtækjanna pó einnig jákvæð frá árinu 2009 hvað varðar reiðufjárhlutfall en staða meðalstórra fyrirtækja tók ekki jafnmiklum breytingum til batnaðar fyrr en síðasta árið í úrtaki. Heilt yfir má sjá hvernig stórum fyrirtækjum hefur tekist betur en

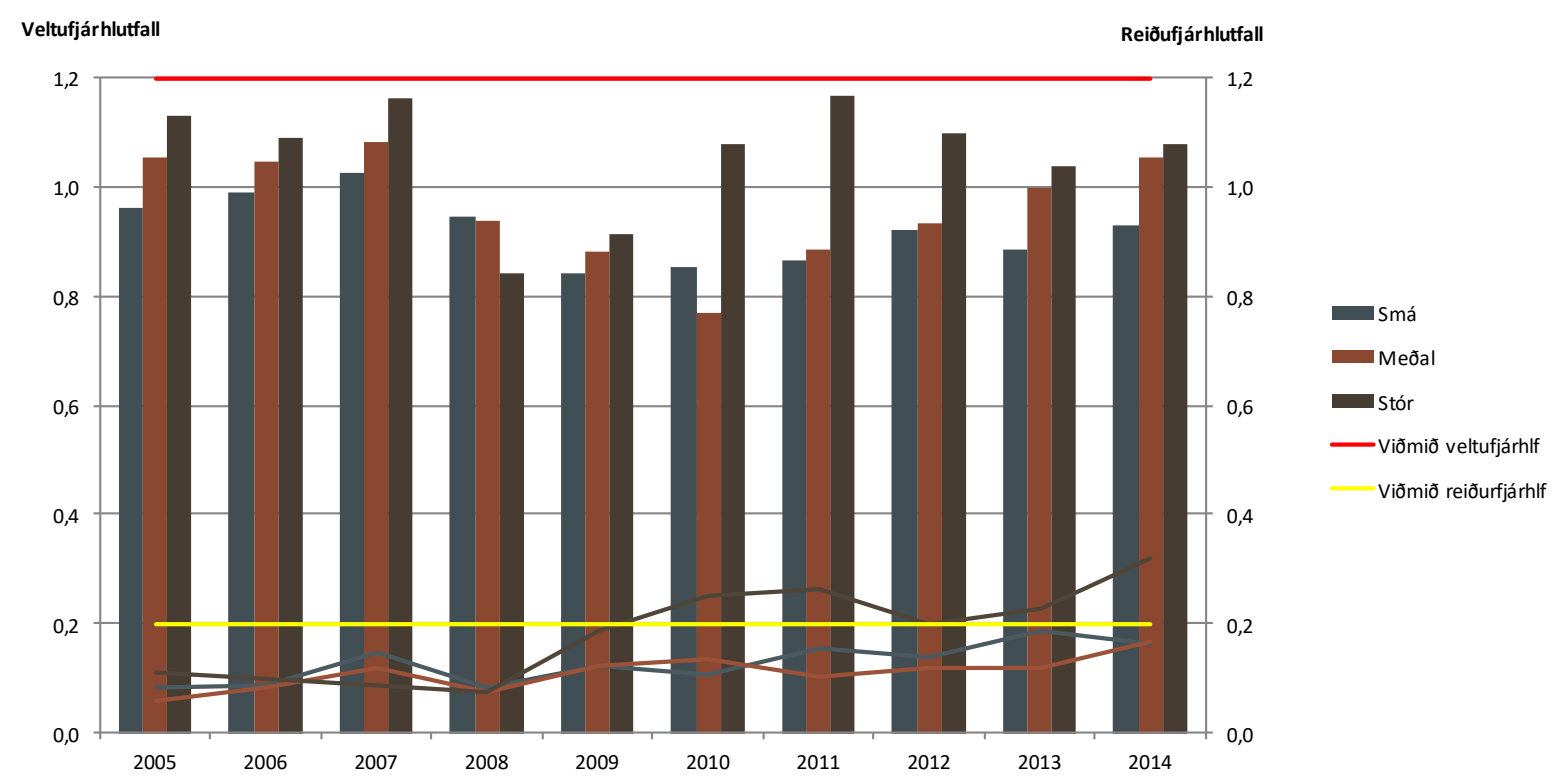

Mynd 8. Greiðsluhæfi fyrirtækja árin 2005-2014, miðað við veltufjárhlutfall og reiðufjárhlutfall, greint eftir stærðarflokkum.

smáum og meðalstórum að greiða úr skuldavanda sínum og aðlaga rekstur að breyttu umhverfi í kjölfar efnahagshrunsins og er pað í samræmi við mælikvarða um skuldsetningu. 


\subsubsection{Arðsemi}

Arðsemi eigna mælt sem EBITDA á móti heildareignum endurspeglar skilvirkni núverandi eigna við að skapa hagnað fyrir fyrirtækið. Arðsemi eigna fer að miklu leyti eftir eignamagni og er pví ólík milli fyrirtækja.

Mynd 9 sýnir próun meðalarðsemi fyrirtækja af mismunandi stærð eftir árum. Smærri fyrirtæki skila að meðaltali meiri arðsemi en stór. Er pað andstætt rannsóknum sem sýna að arðsemi eigna sé oft lægri hjá smáum fyrirtækjum (Hughes, 1997). Verður áhugavert að sjá hvaða áhrif arðsemi hefur í aðhvarfsgreiningu pegar búið er að taka út áhrif annarra pátta á skuldsetningu svo sem stærð. Próun arðsemi smárra og meðalstórra fyrirtækja milli ára er í samræmi við pað sem við er að búast, jókst lítillega árin fyrir efnahagshrun, lækkaði til ársins 2010 pegar hún jókst frá ári til árs. Arðsemi ársins 2014 er líkari pví sem sást á árum fyrir hrun. Áhyggjuefni hlýtur að vera að stór fyrirtæki skila að jafnaði 7,0\% arðsemi öll árin, sem er umtalsvert undir áætluðum vegnum fjármagnskostnaði stórra fyrirtækja á Íslandi ${ }^{12}$. Samkeppniseftirlitið (2013) skoðaði arðsemi fjármagns í ársreikningum 120 stærstu fyrirtækja landsins. Að peirra mati var arðsemi fyrirtækja sem pörfnuðust endurskipulagningar eftir hrun minni en eðlilegt getur talist og var um 70\% peirra með ósjálfbæra arðsemi miðað við $10 \%$ arðsemiskröfu. Hætt er við að enn verði pörf á endurskipulagningu fyrirtækja með litla arðsemi og lága ávöxtun eigin fjár. Próun arðsemi stórra fyrirtækja eins og hún kemur fyrir hér í pessari rannsókn ýtir undir áhyggjur af pessu, pví eftir að hafa náð sér á strik árið 2011 pegar mörg peirra voru undir verndarvæng fjármálafyrirtækja, dró ár frá ári úr henni aftur og árið 2014 var arðsemi eignamestu fyrirtækjanna einungis 5,5\%.

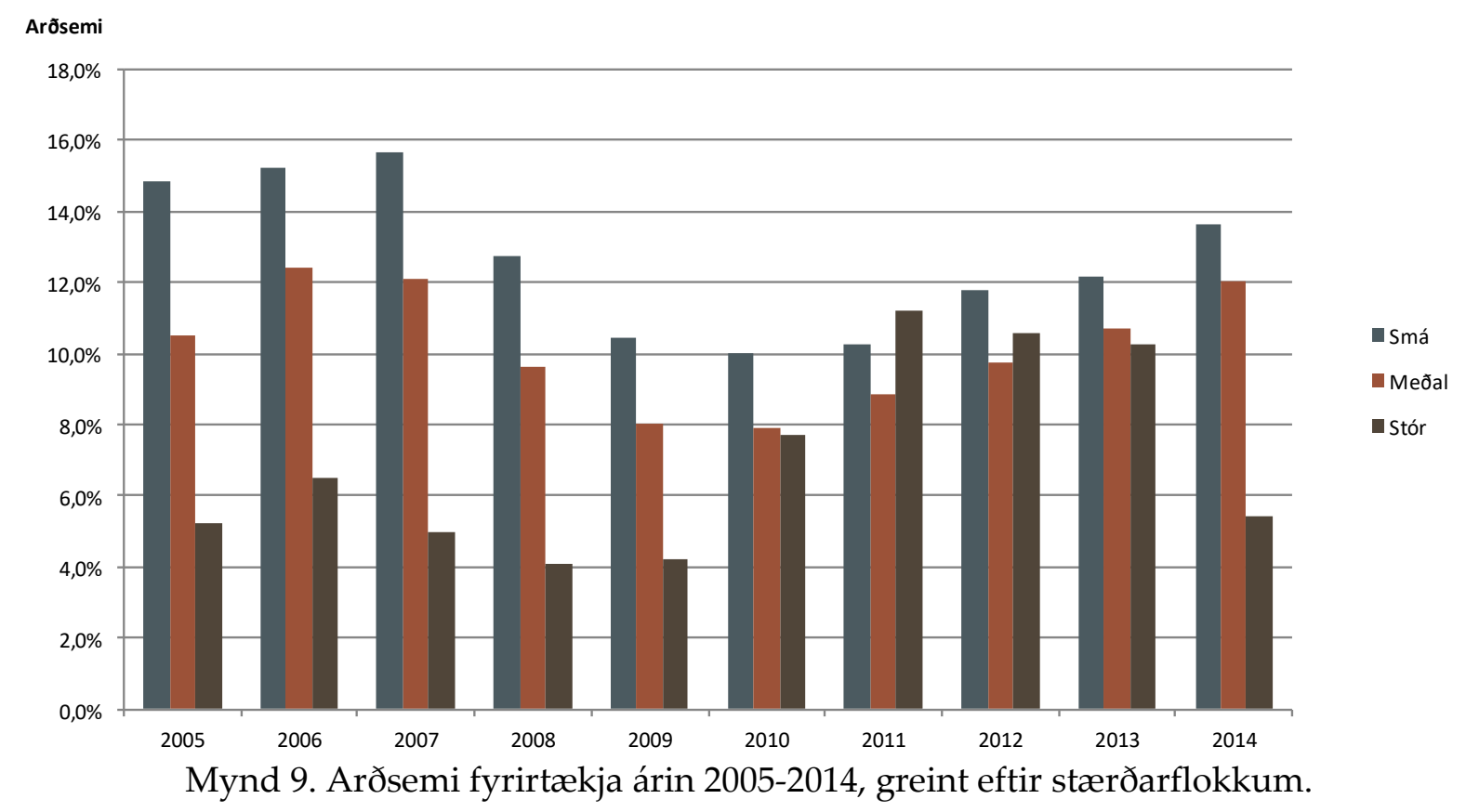

\subsection{Fjölbreytu aðhvarfsgreining}

Úrvinnsla fór fram í tölfræðiforritunum gretl og SPSS. Lýsandi tölfræði frum- og fylgibreyta má finna í töflu 1. Heildarskuldsetning íslenskra fyrirtækja er að meðaltali 0,93 (sf=1,42) öll

12 Áætla má að veginn fjármagnskostnaður stórra fyrirtækja á Íslandi hafi verið um 10\% árið 2013 (Samkeppniseftirlitið, 2013). Stofnunin reiknar arðsemi með aðeins öðrum hætti en hér er gert og miðar við rekstrarhagnað fyrir vexti og skatta (EBIT) í hlutfalli við heildarfjármagn að frádregnum viðskiptaskuldum. 
árin en miðgildi er nokkuð lægra eða 0,85 sem bendir til pess að heildarskuldsetning sé jákvætt skekkt. Hér er meðaltal byggt á skuldsetningu hvers fyrirtækis fyrir sig og vegur pví hvert peirra jafnpungt í meðaltali ólíkt pví pegar notaðar eru samtölur eins og í kaflanum hér á undan. Undirstrikar petta hversu skuldsett fyrirtæki hérlendis eru í raun og veru. Langtímaskuldir voru 38,4\% (sf=0,67) af heildareignum að meðaltali en skammtímaskuldir um $53 \%(\mathrm{sf}=1,23)$, sem endurspeglar fjármagnsskipan meirihluta fyrirtækja í úrtaki eða eignaminni fyrirtækja. Eru pessar niðurstöður í samræmi við niðurstöður áðurnefndra rannsókna (Hughes, 1997). Fastafjármunir í hlutfalli við heildareignir voru að meðaltali 0,52(sf=0,36). Sjá má að dreifing arðsemi eigna var afar mikil, en arðsemi 68,27\% fyrirtækja (eitt staðalfrávik) var á bilinu -21,0\% til 46,5\%. Meðalarðsemi var 12,8\% en miðgildi heldur lægra enda mörg fyrirtæki með neikvæða arðsemi sum ár (sjá töflu 1).

Tafla 1. Lýsandi tölfræði.

\begin{tabular}{lrrrrrrrr}
\hline & $\mathrm{N}$ & Meðaltal & Miðgildi & Sf & Min & Max & $5 \%$ & $95 \%$ \\
\hline y1_HEILD & 81.857 & 0,9316 & 0,8482 & 1,4222 & $-0,1058$ & 219,5000 & 0,0900 & 2,0507 \\
y2_LT & 81.857 & 0,3844 & 0,1771 & 0,6647 & -9.4293 & 57,6414 & 0,0000 & 1,3037 \\
y3_ST & 81.857 & 0,5337 & 0,3861 & 1,2331 & $-0,3464$ & 219,5000 & 0,0193 & 1,3575 \\
x1_InEIGN & 81.857 & 11,2910 & 10,9330 & 1,4030 & 9,6163 & 20,8240 & 9,7699 & 14,0580 \\
x2_ALDUR & 81.857 & 11,5210 & 8,5479 & 10,410 & 0,0000 & 88,1340 & 1,1318 & 36,9560 \\
x3_EFNISL & 81.857 & 0,5184 & 0,5390 & 0,3590 & $-0,2250$ & 1,8767 & 0,0000 & 0,9969 \\
x4_ARĐSEMI & 72.725 & 0,1275 & 0,0951 & 0,3371 & $-24,1717$ & 22,6231 & $-0,1684$ & 0,5477 \\
x5_AFSKR & 72.725 & 0,0437 & 0,0257 & 0,0988 & $-4,4009$ & 10,7885 & 0,0000 & 0,1476 \\
\hline
\end{tabular}

Tafla 2. Fylgni milli breyta í aðhvarfsjöfnu.

\begin{tabular}{|c|c|c|c|c|c|c|c|c|}
\hline & y1 & y2 & y3 & $\mathrm{x} 1$ & $x 2$ & $x 3$ & $\mathrm{x} 4$ & $x 5$ \\
\hline & HEILD & $\mathrm{LT}$ & ST & $\operatorname{lnEIGN}$ & ALDUR & EFNISL & ARĐSEMI & AFSKR \\
\hline y1_HEILD & 1,000 & 0,423 & 0,844 & $-0,039$ & $-0,044$ & 0,090 & $-0,163$ & 0,045 \\
\hline y2_LT & & 1,000 & $-0,045$ & 0,023 & $-0,044$ & 0,308 & $-0,094$ & 0,039 \\
\hline y3_ST & & & 1,000 & $-0,060$ & $-0,029$ & $-0,066$ & $-0,131$ & 0,030 \\
\hline x1_lnEIGN & & & & 1,000 & 0,185 & 0,140 & $-0,056$ & $-0,079$ \\
\hline x2_ALDUR & & & & & 1,000 & $-0,086$ & 0,021 & $-0,035$ \\
\hline x3_EFNISL & & & & & & 1,000 & $-0,121$ & $-0,098$ \\
\hline x4_ARĐSEMI & & & & & & & 1,000 & 0,112 \\
\hline x5_AFSKR & & & & & & & & 1,000 \\
\hline
\end{tabular}

\subsubsection{Marglínuleiki}

Sterkasta fylgni frum- og fylgibreyta mældist milli efnislegra eigna og langtímaskuldsetningar $(\mathrm{r}=0,308, \mathrm{p}=0,005)$ sem kemur ekki á óvart. Fylgni milli frumbreyta var almennt veik eða mjög veik $(r<0,19, \mathrm{p}=0,005$ fyrir allar breytur) og gaf ekki tilefni til að halda að marglínuleiki væri til staðar í gögnunum (sjá töflu 2). Pegar VIF-tölur nálgast 1 er marglínuleiki nánast enginn og eins og sjá má í töflu 3, voru pær mjög nálægt pví. Í ljósi fylgni frumbreyta og VIF-talna má pví fullyrða að marglínuleiki hafi ekki háð greiningunni. 


\subsubsection{Niðurstöður FEM}

Byrjað var á að gera samsetta OLS greiningu (pooled OLS) með öllum frum- og fylgibreytum, auk gervibreyta til að ganga úr skugga um að slík greining væri ekki fullnægjandi fyrir gögnin. Fyrst var einsleitni prófuð með White og Breusch-Pagan prófum og kom í ljós að pau voru bæði marktæk. Núlltilgátunni um einsleitni var pví hafnað og var ekki hægt að útiloka að misdreifni væri til staðar í gögnum. Eftir athugun á dreifingu leifaliða var ákveðið að leiðrétta fyrir misdreifni og eiginfylgni með pví að gera greiningarnar harðgerar (heteroskedasticity and autocorrelation consistent e. HAC). Breytti pað staðalvillu hallatalna lítið eitt, pannig að misdreifnin var ekki mikil.

Panel prófun á OLS greiningunni leiddi í ljós að F-próf á mismun á meðaltölum fyrirtækjanna var marktækt $\left(F_{(15483,57214)}=2,028, p<0,000\right)$, sem benti til pess að samsetta greiningin væri ekki fullnægjandi og að FEM gæfi skilvirkara mat á stuðlum en OLS. BreuschPagan benti til pess að slembin áhrif væru til staðar $(L M=7344,4, p=0)$. Leiddi Hausman-próf pó í ljós að FEM ætti betur við en REM (random-effects model) $(H=2317,61, p<0,000)$, auk pess sem fyrirtækin eru ekki slembiúrtak úr stærra pýði og pví á FEM betur við. Par sem mestur áhugi var á að kanna mun á skuldsetningu áranna 2005, 2009 og 2014 var ákveðið að nota einungis pessar gervibreytur í FEM (sjá töflu 4) til að bera pessi ár saman við önnur.

Tafla 3. VIF tafla.

\begin{tabular}{lc}
\hline & VIF \\
\hline x1_lnEIGN & 1,074 \\
x2_ALDUR & 1,068 \\
x3_EFNISL & 1,058 \\
x4_ARĐSEMI & 1,033 \\
x5_AFSKR & 1,034 \\
\hline
\end{tabular}

Tafla 4. FEM með leiðréttri staðalvillu (HAC).

\begin{tabular}{|c|c|c|c|c|c|c|c|c|c|}
\hline & \multicolumn{3}{|c|}{ y1_HEILD } & \multicolumn{3}{|c|}{ y2_LT } & \multicolumn{3}{|c|}{ y3_ST } \\
\hline & Stuðull & $\mathrm{t}$ & $\mathrm{p}$ & Stuðull & $\mathrm{t}$ & $\mathrm{p}$ & Stuðull & $\mathrm{t}$ & $\mathrm{p}$ \\
\hline Fasti & 5,9496 & 4,873 & $<0,0001^{* * *}$ & 1,1941 & 4,112 & $<0,0001^{* * *}$ & 4,7307 & 3,949 & $<0,0001^{* * *}$ \\
\hline x1_lnEIGN & $-0,4706$ & $-4,100$ & $<0,0001^{* * *}$ & $-0,0936$ & $-3,573$ & $0,0004^{* * *}$ & $-0,3761$ & $-3,335$ & $0,0009^{* * *}$ \\
\hline x2_ALDUR & 0,0134 & 4,308 & $<0,0001^{* * *}$ & 0,0070 & 6,322 & $<0,0001^{* * *}$ & 0,0066 & 2,204 & $0,0276^{* *}$ \\
\hline x3_EFNISL & 0,3186 & 3,376 & $0,0007^{* * *}$ & 0,3560 & 9,387 & $<0,0001^{* * *}$ & $-0,0329$ & $-0,375$ & 0,7079 \\
\hline $\begin{array}{l}\text { x4_ARĐSEM } \\
\text { I }\end{array}$ & $-0,2574$ & $-0,645$ & 0,5187 & $-0,0792$ & $-3,733$ & $0,0002^{* * *}$ & $-0,1794$ & $-0,447$ & 0,6551 \\
\hline x5_AFSKR & 0,3307 & 1,385 & 0,1659 & 0,1194 & 1,920 & $0,0548^{*}$ & 0,2034 & 0,899 & 0,3689 \\
\hline dt_2005 & $-0,1170$ & $-7,106$ & $<0,0001^{* * *}$ & $-0,0629$ & $-11,370$ & $<0,0001^{* * *}$ & $-0,0527$ & $-3,357$ & $0,0008^{* * *}$ \\
\hline dt_2009 & 0,1362 & 12,160 & $<0,0001^{* * *}$ & 0,1005 & 15,870 & $<0,0001^{* * *}$ & 0,0354 & 3,531 & $0,0004^{* * *}$ \\
\hline dt_2014 & $-0,0537$ & $-1,562$ & 0,1183 & $-0,0727$ & $-14,710$ & $<0,0001^{* * *}$ & 0,0139 & 0,408 & 0,6836 \\
\hline y1_HEILD & \multicolumn{3}{|c|}{$F_{(15483,57214)}=2,028, p<0,000$} & \multicolumn{3}{|c|}{$R^{2}=0,3812$} & \multicolumn{2}{|c|}{ Akaike criterion } & 247.106 \\
\hline y2_LT & \multicolumn{3}{|c|}{$F_{(15483,57214)}=4,611, p<0,000$} & \multicolumn{3}{|c|}{$R^{2}=0,6127$} & \multicolumn{2}{|c|}{ Akaike criterion } & 98.464 \\
\hline y3_ST & \multicolumn{3}{|c|}{$F_{(15483,57214)}=1,650, p<0,000$} & \multicolumn{3}{|c|}{$R^{2}=0,3296$} & \multicolumn{2}{|c|}{ Akaike criterion } & 240.187 \\
\hline
\end{tabular}


Eins og sjá má á töflu 4 voru öll prjú líkön marktæk með meira en 99,99\% líkum. Skýribreyturnar virðast skýra 38,12\% af dreifingu heildarskuldsetningar, 61,27\% af dreifingu langtímaskuldsetningar og 32,96\% af dreifingu skammtímaskuldsetningar (sjá $F$-próf og $R^{2}$ í töflu 4). Pegar búið var að taka út áhrif annarra breyta höfðu allar breytur nema arðsemi, afskriftir og gervibreyta ársins 2014 marktæk áhrif á heildarskuldsetningu miðað við 95\% öryggismörk (sjá t-próf í töflu 4) og allar nema afskriftir á langtímaskuldsetningu. Efnislegar eignir, arðsemi, afskriftir og gervibreyta fyrir árið 2014 höfðu ekki marktæk áhrif á skammtímaskuldsetningu. Komu tengsl frumbreyta við fylgibreytu nokkuð á óvart miðað við kenningar og niðurstöður annarra rannsókna, par sem pau voru í öfuga átt við pað sem spáð var fyrir um í tilviki stærðar, aldurs og afskrifta, en efnislegar eignir og arðsemi eigna voru pó í samræmi við tilgátur. Miðað við pað sem fram hefur komið í umfjöllun um niðurstöður hingað til var pó við pví að búast.

\section{Stærð}

Aðhvarfsgreining leiddi í ljós að ef heildareignir aukast um 1\% pá dregur 0,47\% úr skuldsetningu. Er petta hvorki í samræmi við fórnarskiptakenninguna né fyrri rannsóknir en styður við pá tilgátu að stór fyrirtæki kljáist síður við ósamhverfar upplýsingar en smá og ættu pví fremur að geta fjármagnað sig með eigin fé. Röðun fjármögnunarkosta ætti pví að geta skýrt lága skuldsetningu stórra fyrirtækja í úrtaki. Var ekki hægt að hafna núlltilgátunni og pví var tilgátu 1 um að stærð hafi jákvæð tengsl við heildarskuldir hafnað. Sömu sögu má segja um langtímaskuldir og skammtímaskuldir, en svo virðist sem stærri fyrirtæki skuldi minna sem hlutfall af heildareignum óháð tegund skulda. Geta stærri fyrirtækja til að fjármagna sig á hlutabréfamörkuðum er umtalsvert meiri en eignaminni fyrirtækja og pví ná pau líklega betur en smá að stilla skuldum í hóf í fjármagnsskipan sinni. Par sem ekki er virkur markaður með óskráð bréf og skráning kostnaðarsöm fyrir minni fyrirtæki getur pví verið að takmarkað aðgengi eignaminni fyrirtækja að öðru en lánsfjármagni valdi pessum tengslum hérlendis en eins og fram hefur komið er pað nokkuð frábrugðið pví sem tíðkast erlendis (OECD, 2015c).

\section{Aldur}

Aldur hefur samkvæmt niðurstöðum jákvæð tengsl við skuldsetningu óháð tegund ef áhrifum annarra breyta er stjórnað, en með hverju aldursári fyrirtækja eykst heildarskuldsetning um 1,3\%, langtímaskuldsetning um $0,7 \%$ og skammtímaskuldsetning um $0,7 \%$ einnig. Tilgátu 2 var pví hafnað (sjá töflu 4). Samkvæmt fórnarskiptakenningunni eru fyrirtæki með lengri rekstrarsögu síður líkleg en ung til að lenda í fjárhagslegum erfiðleikum og gjaldproti og pví ættu pau að pola hærri skuldabyrði. Má pví færa rök fyrir pessum niðurstöðum með tilvísan í fórnarskipti, en eldri fyrirtæki hafa tilhneigingu til að vera meira skuldsett en pau yngri. Ef til vill má einnig skýra pessar niðurstöður með tilvísan í tengsl fyrirtækja við fjármálastofnanir eða reynslu banka af fyrirtækjum og stjórnendum peirra. Slík tengsl geta komið í stað veðhæfra eigna pegar kemur að skuldsetningu með langtímalánum og á pað sérstaklega við um minni fyrirtæki (Berger og Udell, 1998; Voordeckers og Steijvers, 2006).

\section{Efnislegar eignir}

Í langflestum rannsóknum eru efnislegar eignir skilgreindar sem fastafjármunir í hlutfalli við heildareignir en pað hlutfall skiptir miklu fyrir veðhæfi eigna. Í ljósi pess hve lítil dreifing var í breytunni efnislegar eignir var ákveðið að nota sömu skilgreiningu á efnislegum eignum hér. Í samræmi við bæði fórnarskiptakenninguna og röðun fjármögnunarkosta var pví spáð að efnislegar eignir myndu stuðla að skuldsetningu með langtíma- og heildarskuldum, pví 
veðhæfar eignir draga úr umboðsvanda og upplýsingamisræmi og bæta par af leiðandi aðgengi að lánsfjármagni. Voru niðurstöður í samræmi við tilgátu og má með vissu fullyrða að fyrirtæki með meiri efnislegar eignir séu meira skuldsett. Stóðst pví tilgáta 3 (sjá töflu 4). Voru tengsl við skammtímaskuldir ómarktæk, sem bendir til að aðrir pættir en veð í eignum stýri aðgengi að skammtímaskuldum. Með línulegum aðhvarfsgreiningum fyrir hvert ár í senn sést að veðhæfni eigna skýrir öll ár hlutfallslega mest af breytileika langtímaskuldsetningar eins og sjá má á staðlaðri betu.

\section{Arðsemi}

Ef tekin eru út áhrif annarra breyta hefur arðsemi neikvæð tengsl við langtímaskuldir. Petta bendir til pess að arðsöm fyrirtæki purfi ekki að nota skuldir til að fjármagna sig til langs tíma pví óráđstafað eigið fé sem er framar í forgangsröðuninni er nægt til að standa undir fjárfestingum. Fjórða tilgátan stóðst pví með tilliti til langtímaskulda (sjá töflu 4). Ef línulegar aðhvarfsgreiningar eru skoðaðar fyrir hvert ár í senn, kemur í ljós að öll ár skýrir arðsemi hlutfallslega mest af breytileika heildar- og skammtímaskuldsetningar, eins og sjá má á staðlaðri betu. Tengsl milli heildar- og skammtímaskulda og arðsemi eigna voru pó ómarktæk í margvíðu sniði.

\section{Afskriftir}

Athyglisvert er að pví meiri afskriftir sem fyrirtæki bókfæra, peim mun skuldsettari eru pau til langs tíma. Tengsl afskrifta og heildar- og skammtímaskuldsetningar eru ómarktæk ( $p=0,166$ og $p=0,369$ ), en fimmtu tilgátunni er engu að síður hafnað. Eins og fram hefur komið gerir fórnarskiptakenningin ráð fyrir að pessi tengsl séu neikvæð, en niðurstöður rannsókna hafa verið misvísandi. Hugsanlegt er að afskriftir komi ekki í staðinn fyrir skattahagræði skulda eins og haldið hefur verið fram, heldur séu viðbót við pað. Er pað í samræmi við niðurstöður Harris og Raviv (1991). Einnig kann að vera að tengsl pessi séu flóknari en líkanið gefi til kynna og að samvirkni milli afskrifta og fastafjármuna eða arðsemi sé um að kenna. Parf að greina pað betur til að fullyrða um pað.

\section{Tími}

Rannsóknir hafa sýnt að efnahagssveiflur hafa áhrif á skuldsetningu, sérstaklega smárra fyrirtækja sem hafa einsleitari rekstur og eru pví viðkvæmari ef illa árar. Eins benda sumar rannsóknir til pess að fyrirtæki utan markaðar séu nær eingöngu fjármögnuð með lánsfé sem gerir pau næmari fyrir verðbólgu og gengisáhrifum. Í ljós kom, eins og við var að búast, að árið 2005 var skuldsetning óháð tegund marktækt minni en önnur ár. Árið 2009 var hún marktækt meiri en ekki var marktækur munur á heildar- og skammtímaskuldsetningu ársins 2014 miðað við önnur ár. Má pví fullyrða að tími hafi haft áhrif á langtíma-skuldsetningu pessi ár og stóðst pví tilgáta 6 með tilliti til langtímaskulda. Skýringar á pví eru væntanlega eins og áður var rætt; gengisfall, aukin verðbólga, samdráttur innlendrar eftirspurnar og tekjuskerðing samhliða henni olli skuldaaukningu sem erfitt varð að vinda ofan af. Skömmu eftir hrun áttu fyrirtæki fáa aðra fjármögnunarkosti en aukna lántöku á háum vöxtum og virðast pau hafa pegið pað fjármagn sem peim bauðst. Skýrir pað að hluta hvers vegna skuldastaða smárra félaga versnaði mun meira í efnahagshruninu en stærri fyrirtækja sem hafa að öllum líkindum boðist hagstæðari kjör á skuldamörkuðum. 


\section{Umræða}

Meginmarkmið með rannsókninni var að kanna fjárhagslega stöðu og fjármagnsskipan fyrirtækja á Íslandi árin 2005 til 2014. Með pví að greina fyrirtæki af ólíkri stærð var um leið bætt úr skorti á rannsóknum á eignaminni fyrirtækjum sem háð hefur umræðunni hérlendis. Var áhersla lögð á skuldsetningu enda voru vísbendingar um að fjármögnun fyrirtækja væri vandkvæðum bundin, pó einkum smárra og meðalstórra sem eiga fæst kost á útgáfu skulda og hlutafjár á skipulögðum verðbréfamarkaði. Var peirri spurningu velt upp hvort fyrirtæki hafi verið of skuldsett í aðdraganda hrunsins og hvort peim hafi tekist að greiða úr skuldavanda sínum eftir hrun. Pá var reynt að greina í hverju skuldavandinn fólst, pað er hvaða pættir hafa áhrif á skuldsetningu.

Eins og áđur hefur komið fram fór skuldastaða fyrirtækja á Íslandi versnandi í aðdraganda efnahagshrunsins og áttu mörg hver í erfiðleikum við að bregðast við peim aðstæðum sem upp komu. Skömmu eftir hrun virðast fyrirtæki hafa átt fáa aðra fjármögnunarkosti en aukna lántöku hjá fjármálafyrirtækjum á háum vöxtum, en hreinar skuldir jukust um tæpan helming á árinu 2008. Ljóst er að hátt hlutfall gengis- og verðtryggðra lána hafði umtalsverð áhrif á efnahagsreikninga eftir fall fjármálakerfisins. Á árinu 2008 jókst skuldsetning að pví marki að nær helmingur fyrirtækja í landinu skilaði neikvæðu eigin fé. Af peim fyrirtækjum sem voru tæknilega gjaldprota, voru pó mörg með lífvænlegan rekstur. Umfangsmiklar samræmdar aðgerðir við úrvinnslu skuldamála leiddu til pess að í árslok 2014 var skuldastaða orðin svipuð pví sem hún var árin fyrir efnahagshrun, sem pýðir pó að skuldsetning fyrirtækja hérlendis var enn fremur há.

Margar og samverkandi ástæður eru fyrir pví að skuldastaða fyrirtækja eftir hrun var ekki eins og best verður á kosið. Fyrst ber að nefna að vextir, gengislækkun krónunnar og verðbólga í sambland við samdrátt innlendrar eftirspurnar átti sinn pátt í pví að hægt gekk að leysa úr skuldavandanum sem myndaðist í bankahruninu. Óvissa tengd lögmæti gengistryggðra lánasamninga átti par einnig hlut að máli. Má almennt segja að í hruninu virtust flestar fjárfestingar vera áhættusamar og vilji til að fjárfesta pví lítill. Innlánsvextir hækkuðu mikið um tíma og náðu innlán innlendra aðila í bankakerfinu hámarki í september 2009, er fjármagn tók að færast í bundnari eignir svo sem verðbréfasjóði sem fjárfestu eingöngu í ríkisskuldabréfum. Upphaf efnahagsbata mátti greina um mitt ár 2010 og fljótlega upp úr pví virðast fjárfestar í auknum mæli hafa farið að horfa til fasteigna- og hlutabréfamarkaða (Seðlabanki Íslands, 2011b), auk pess sem fjárfesting í óskráðum eignum jókst vegna fárra fjárfestingakosta. Jafnvel pótt umtalsvert hafi dregið úr skuldavanda fyrirtækja á árunum 2010-2014 og staða stórra fyrirtækja að mörgu leyti verið orðin góð, voru fyrirtæki pó enn fremur skuldsett í alpjóðlegu samhengi (OECD, 2015a; Samkeppniseftirlitið, 2012).

Á pessum áratug sem hér er til skoðunar er skuldsetning ráðandi fjármögnunarkostur hjá íslenskum fyrirtækjum almennt sem eykur næmi fyrir efnahagslegum niðursveiflum. Efnahagsumhverfið hérlendis hefur verið sveiflukennt í gegnum tíðina og pví ef til vill heppilegra að eiginfjárstaða fyrirtækja sé sterkari en par sem sveiflur eru minni (Steinn Friðriksson, 2015). Verðlag á Íslandi hefur verið mun óstöðugra en í nágrannalöndunum allt frá pví fyrir lýðveldisstofnun og gengi krónunnar sveiflast að sama skapi auk pess sem hagsveiflur hafa verið djúpar, meðal annars vegna smæðar hagkerfisins, lítils aga í hagstjórn og sveiflna sem eru nær óhjákvæmilegar í sjávarútvegi, mikilvægustu útflutningsgrein landsins lengst af á 20. öldinni (Bjarni G. Einarsson, Guðjón Emilsson, Svava J. Haraldsdóttir, Pórarinn G. Pétursson og Rósa B. Sveinsdóttir, 2013). 
Hugsanlegt er að skattalegir hvatar ýti undir skuldsetningu fyrirtækja og myndi slagsíðu í fjármagnsskipan fyrirtækja skuldsetningu í vil. Frádráttur vaxtagreiðslna frá tekjum af atvinnurekstri er leyfður, en fyrirtækjum er ekki heimilt að draga arðgreiðslur til einstaklinga frá tekjuskattstofni. Í greinargerð Alpjóða gjaldeyrissjóðsins voru lagðar til breytingar á skattalöggjöf sem sneru að pví að heimila frádrátt eðlilegrar ávöxtunar eigin fjár frá tekjuskattstofni í peim tilgangi að sampætta betur skattlagningu fyrirtækja og einstaklinga og draga úr hvötum til punnrar eiginfjármögnunar. Að peirra mati varð mikil skuldsetning fyrirtækja á Íslandi til pess að dýpka mjög efnahagslægðina á Íslandi jafnvel pótt umrædd skuldabjögun hafi ekki valdið henni beint (Alpjóða gjaldeyrissjóðurinn, 2010). Ekki er pó víst að liðinn áratugur sé mjög lýsandi fyrir fjármagnsskipan fyrirtækja á Íslandi í sögulegu samhengi. Hefði pví verið áhugavert að skoða fleiri ár aftur í tímann. ${ }^{13}$ Eins er fróðlegt að fylgjast með próuninni nú, en vísbendingar eru um að hrein útlán bankanna séu að aukast á ný (Seðlabanki Íslands, 2015b).

Ljóst er að erfiðar aðstæður á fjármagnsmörkuðum eftir hrun bitnuðu á öllum íslenskum fyrirtækjum óháð stærð, en pó kom vandinn sérstaklega illa við smærri fyrirtækin í landinu. Svigrúm flestra fyrirtækja til að mæta áfalli sem pessu er mjög takmarkað, en pó sérstaklega peirra sem ekki sjá sér fært að sækja fjármagn á verðbréfamarkaði og eru háðari lántöku hjá fjármálastofnunum. Auk pess voru pau skuldsettari fyrir hrun, pannig að vaxtakjör sem peim hafa staðið til boða eftir hrun hafa án efa verið mjög óhagstæð. Var staða eignameiri fyrirtækja ekki alveg jafnslæm, en meiri líkur eru á að pau hafi að einhverju leyti verið varin fyrir gengisáhrifum. Einnig hefur samningsstaða peirra gagnvart lánardrottnum eflaust verið betri, enda meiri hagsmunir í húfi. Skýrir pað hvers vegna skuldaaukning minni félaga eftir fjármálaáfallið varð mun meiri en eignameiri fyrirtækja og hvers vegna stærri fyrirtæki hafa náð að vinna sig betur út úr hruninu fjárhagslega.

Ýmis merki eru um að fjármögnunarleiðum fyrirtækja sem hafa verið of smá fyrir aðallista Kauphallarinnar sé að fjölga. T.d. voru heimildir lífeyrissjóða til að fjárfesta í óskráðum bréfum á markaðstorgi fjármálagerninga (First North) rýmkaðar með lögum nr. 54/2015. Á peim markaði er regluverkið léttara, upplýsingaskylda minni og kostnaður við skráningu lægri. Koma pær líklega einkum til með að fjölga fjármögnunarleiðum peirra fyrirtækja sem hafa verið of smá fyrir aðallista Kauphallarinnar og auka almenna fjárfestingu í hlutabréfum. (Páll Harðarson, 2015).

Aðrar niðurstöður voru pær að greiðsluhæfi fyrirtækja virtist almennt vera mjög lítið sem styður að skuldsetning hafi verið óhófleg öll ár í úrtaki. Til dæmis leiddi greiningin í ljós að skuldir á móti EBITDA voru yfir viðmiðum jafnvel áður en fjármálaáfallið dundi yfir. Greinilegt er að í rekstri margra fyrirtækja hefur verið gert ráð fyrir hækkandi eignavirði og getu til að auka skuldsetningu vegna pess. Arðsemi stórra fyrirtækja var fremur lág, en smærri fyrirtæki skiluðu að meðaltali meiri arðsemi eigna öll ár nema árið 2011. Pá höfðu bankar

${ }^{13}$ Allt par til verðtrygging var leyfð árið 1979 og vextir gefnir frjálsir á níunda áratugi síðustu aldar voru raunvextir bæði inn- og útlána á Íslandi neikvæðir flest ár og lánsfé skammtað. Keyrði um pverbak í mikilli verðbólgu á áttunda áratuginum og í upphafi pess níunda. Fjármögnun fyrirtækjarekstrar við slík skilyrði laut allt öðrum lögmálum en nú. Pá má einnig hafa í huga að almennur hlutabréfamarkaður varð ekki til hérlendis fyrr en á níunda áratug síðustu aldar og skráning hlutabréfa í kauphöll hófst ekki fyrr en fyrir tæpum aldarfjórðungi, mun síðar en í öllum nágrannalöndum okkar í Vestur-Evrópu. (Gylfi Magnússon, 2007). Pessi forsaga kann enn að móta rekstrar- og fjármögnunarumhverfi íslenskra fyrirtækja að einhverju marki en pað er efni í sjálfstæða rannsókn og verður ekki skoðað hér. 
ráðandi stöðu í um helmingi allra stærstu fyrirtækja landsins en mörg peirra höfðu lokið fjárhagslegri endurskipulagningu og tekið til í rekstri (Samkeppniseftirlitið, 2011).

Niðurstöður aðhvarfsgreiningar komu að sumu leyti á óvart ef tekið er mið af peim kenningum og niðurstöðum rannsókna sem greint var frá í upphafi. Pegar tekin voru út áhrif annarra pátta voru eignameiri fyrirtæki og yngri minna skuldsett, sem var öfugt við pær tilgátur sem settar voru fram. Sömuleiðis höfðu afskriftir jákvæð tengsl við langtímaskuldir pvert á pað sem við höfðum vænst. Félög með miklar efnislegar eignir og minna arðsöm fyrirtæki voru pó meira skuldsett sem var í samræmi við tilgátur. Marktæk áhrif tímabreyta benda til pess að skuldsetning pessara ára hafi verið ólík hinum. Til að fá staðfest hvort efnahagssveiflur hafi meiri áhrif á lítil fyrirtæki en stór hefði verið fróðlegt að prófa samvirkni tímabreyta og stærðarflokkunar en pað er efni í aðra rannsókn.

Pótt staðan hafi verið óvenjuleg pessi ár var fjármagnsskipan eignameiri fyrirtækja á Íslandi nokkuð lík peirri sem greint er frá í erlendum rannsóknum og sem byggð er á vali fjármögnunarleiða eða eftirspurn. Fjármagnsskipan smárra fyrirtækja á hinn bóginn lýsir líkast til framboði fjármagns að mestu leyti, en takmarkað framboð annarra fjármögnunarkosta en lánsfjár hefur leitt til mikillar skuldsetningar peirra. Hún endurspeglar pví ekki frjálst val heldur pvingað og uppsafnaða pörf á fjármagni. Hafa rannsóknir í seinni tíð verið gagnrýndar fyrir að taka ekki tilliti til áhrifa framboðs á fjármagnsskipan (Baker, 2009; Graham og Leary, 2011). Hefði verið fróðlegt að gera einnig aðhvarfsgreiningar með stærðarflokkuðum gögnum, pví líklega er pað svo að stór fyrirtæki fylgja betur peim kenningum sem greint var frá í upphafi. Erfitt er að steypa öllum smáum og meðalstórum fyrirtækjum í eitt mót, pví pau eru afar ólík. Kemur pví ekki á óvart að niðurstöður rannsókna sem fela einnig í sér mjög smá fyrirtæki séu síður í samræmi við kenningar.

\section{Lokaorð}

Skuldsetning fyrirtækja var of mikil í aðdraganda efnahagsáfallsins og var staðan svipuð árið 2014. Brýnt er að reyna að draga úr hvötum til skuldsetningar og leggja kapp á að styrkja eiginfjárstöðu til að bæta rekstur fyrirtækja og auka fjárhagslegt svigrúm til að mæta áföllum í efnahagslífinu og á fjármálamörkuðum. Раð er raunar brýnna hérlendis en í nágrannalöndunum vegna óstöðugleika hagkerfisins, sérstaklega gjaldmiðilsins. Hægt er að sampætta betur skattlagningu fyrirtækja og einstaklinga, auðvelda minni fyrirtækjum að sækja fé á verðbréfamarkað og ljúka peirri vinnu sem hafin er við skattaívilnanir fyrir hlutabréfakaup í nýsköpunarfyrirtækjum. Pessar tillögur miða að pví að skapa pann vettvang sem til parf. Til að hvatinn verði réttur er pó mikilvægt að vanda vel til verka.

Gögnin varpa ljósi á afar sérstakt tímabil í sögunni og pví hugsanlega varhugavert að draga mjög víðtækar ályktanir um skuldsetningu fyrirtækja almennt út frá pví. Á árinu 2015 má sjá að hægt hefur á lækkun skulda og hrein ný útlán bankanna til fyrirtækja eru að aukast. Aukið innstreymi erlends fjármagns er meðal fyrstu merkja pess að spenna sé aftur tekin að myndast í pjóðarbúskapnum (Seðlabanki Íslands, 2015b). Við afnám fjármagnshafta myndast skilyrði fyrir innstreymi fjármagns sem ásamt væntingum um góða afkomu og hækkun eignaverðs gæti leitt til skuldabólu og ofpenslu hagkerfisins svipað pví sem gerðist í aðdraganda efnahagshrunsins. Í ljósi pessara aðstæðna er pví aukning eiginfjár sérstaklega brýn. 


\section{Heimildir}

Alpjóða gjaldeyrissjóðurinn (2010). Iceland: Improving the Equity and Revenue Productivity of the Icelandic Tax System. International Monetary Fund. https://www.imf.org/ External/Pubs/FT/SCR/2010/cr10213.pdf.

Atvinnuvega- og nýsköpunarráðuneytið (2012). Greinargerð starfshóps til að vinna tillögur að lagabreytingum og aðgerðum til að verjast kennitöluflakki og til að ná markmiðum laga um jöfnun kynja í stjórnum fyrirtækja. Sótt 10. júní 2015 af vef atvinnuvega- og nýsköpunarráðuneytisins: http://www.atvinnuvegaraduneyti.is/media/Acrobat/ Greinargerd-starfshops.pdf.

Baker, M. (2009). Capital Market-Driven Corporate Finance. The Annual Review of Financial Economics, 1, 181-205. DOI: 10.1146/annurev.financial.050808.114245.

Berger, A. N., og Udell, G. F. (1998). The economics of small business finance: The roles of private equity and debt markets in the financial growth cycle. Journal of Banking and Finance, 22 (6-8), 613-673. DOI: 10.1016/S0378-4266(98)00038-7.

Bjarni G. Einarsson, Guðjón Emilsson, Svava J. Haraldsdóttir, Pórarinn G. Pétursson og Rósa B. Sveinsdóttir (2013). On our own? The Icelandic business cycle in an international context. Working paper no. 63. Central Bank of Iceland. March.

Brav, O. (2009). Access to Capital, Capital Structure, and the Funding of the Firm. The Journal of Finance, 64(1), 263-308. DOI: 10.1111/j.1540-6261.2008.01434.x.

Creditinfo (2015). Creditinfo - Lánstraust, Um Creditinfo. Sótt 8. maí 2015 af vef Creditinfo: https://www.creditinfo.is/um-creditinfo/default.aspx.

Damijan, J. P. (2014). Corporate Financial Soundness and its Impact on Firm Performance: Implications for Corporate Debt Restructuring in Slovenia. Working Paper No. 168. European Bank for Reconstruction and Development.

DeAngelo, H., og Masulis, R. W. (1980). Optimal Capital Structure Under Corporate and Personal Taxation. Journal of Financial Economics, 8(1), 3-27. SSRN: http://ssrn.com/ abstract $=1482270$.

Deloitte (2015). Fjármálaráðgjöf, faglegt efni. Könnun á viðhorfum fjármálastjóra 300 stærstu fyrirtækja landsins. Sótt 15. september 2015 af vef Deloitte: http://www2.deloitte.com/ content/dam/Deloitte/is/Documents/finance/CFOkonnun/CFO\%20survey\%20novem ber\%202014.pdf.

de Jong, A., Verbeek, M., og Verwijmeren, P. (2011). Firms' debt-equity decisions when the static tradeoff theory and the pecking order theory disagree. Journal of Banking and Finance, 35, 1303-1314. DOI: 10.1016/j.jbankfin.2010.10.006.

European Commission (2006). Skilgreining lítilla og meðalstórra fyrirtækja (SME). Leiðbeiningar um notkun og fyrirmynd yfirlýsingar. Sótt 17. maí 2015 af vef Evrópuráðsins: http://ec.europa.eu/enterprise/policies/sme/files/sme_definition/ sme_user_guide_is.pdf.

Fama, E., og French, K. (2002). Testing trade-off and pecking order predictions about dividends and debt. The Review of Financial Studies , 15, 1-33. http://www.jstor.org/ stable/2696797.

Frank, M., og Goyal, V. (2003). Testing the pecking order theory of capital structure. Journal of Financial Economics, 67, 217-248. DOI: 10.1016/S0304-405X(02)00252-0.

Frank, M., og Goyal, V. (2009). Capital Structure Decisions: Which Factors Are Reliably Important? Financial Management, 38(1), 1-37. http://www.jstor.org/stable/20486683. 
Graham, J., og Harvey, C. (2001). The theory and practice of corporate finance: evidence from the field. Journal of Financial Economics, 60, 187-243. DOI: 10.1016/S0304405X(01)00044-7.

Graham, J., og Leary, M. T (2011). A Review of Empirical Capital Structure Research. Annual Review of Financial Economics, 3, 309-345. DOI: 10.2139/ssrn.1729388.

Gujarati, D. N., og Porter, D. C. (2009). Basic Econometrics. Irwin: McGraw-Hill.

Gylfi Magnússon (2007). Markaður verður til: Saga íslenska hlutabréfamarkaðarins. Rannsóknarrit Hagfræðistofnunar Háskóla Íslands. R07:01.

Hagstofa Íslands (2015a). ÍSAT 2008 - Yfirlitstöflur. Sótt 20. apríl 2015 af vef Hagstofu Íslands: http://www.hagstofa.is/lisalib/getfile.aspx?itemid=9774.

Hagstofa Íslands (2015c). Hagstofa Íslands - Talnaefni: Fyrirtæki og velta. Sótt 24. júlí 2015 af vef Hagstofu Íslands: http://www.hagstofa.is/Hagtolur/Fyrirtaeki-og-velta/Fyrirtaeki.

Hall, G., Hutchinson, P. J., og Michaelas, N. (2000). Industry effects on the determinants of unquoted SMEs' capital structure. International Journal of the Economics of Business, 7 (3), 297-312. DOI: 10.1080/13571510050197203.

Hall, G., Hutchinson, P., og Michaelas, N. (2004). Determinants of the capital structures of European SMEs. Journal of Business Finance and Accounting, 31 (5-6), 711-728. DOI: 10.1111/j.0306-686X.2004.00554.x.

Harris, M., og Raviv, A. (1991). The Theory of Capital Structure. The Journal of Finance, 46(1), 297-355. DOI: 10.1111/j.1540-6261.1991.tb03753.x.

Hughes, A. (1997). Finance for SMEs: A U.K. Perspective. Small Business Economics, 9, 151-166. DOI: 10.1023/A:1007971823255.

Hæstiréttur Íslands, Hrd. 9. júní 2011 í máli nr. 155/2011. Landsbankinn hf. gegn protabúi Motormax ehf.

Jensen, M. C. (1986). Agency Cost of Free Cash Flow, Corporate Finance, and Takeovers. American Economic Review, 76(2), 323-329. DOI: http://dx.doi.org/10.2139/ssrn.99580

Jensen, M. C., og Meckling, W. H. (1976). Theory of the Firm: Managerial Behavior, Agency Costs and Ownership Structure. Journal of Financial Economics, 3(4), 305-360. http://www.business.illinois.edu/josephm/BA549_Fall\%202014/Session\%205/5_Jense n_Meckling\%20(1976).pdf.

Kraus, A., og Litzenberger, R. H. (1973). A State-Preference Model of Optimal Financial Leverage. The Journal of Finance, 28(4), 911-922. DOI: 10.2307/2978343.

Leary, M. T., og Roberts, M. R. (2010). The pecking order, debt capacity, and information asymmetry. Journal of Financial Economics, 95, 332-355. DOI: 10.1016/j.jfineco.2009. 10.009 .

López-Gracia, J., og Sogorb-Mira, F. (2008). Testing trade-off and pecing order theories financing SMEs. Small Business Economics, 31 (2), 117-136. DOI: 10.1007/s11187-0079088-4.

Lög nr. 21/1991 um gjaldprotaskipti o.fl.

Lög nr. 38/2001 um vexti og verdtryggingu.

Lög nr. 90/2003 um tekjuskatt.

Lög nr. 3/2006 um ársreikninga.

Lög nr. 151/2010 um breytingu á lögum um vexti og verðtryggingu, lögum um aðgerðir í págu einstaklinga, heimila og fyrirtækja vegna banka- og gjaldeyrishrunsins og lögum um umboðsmann skuldara.

Lög nr. 54/2015 um breytingu á lögum nr. 129/1997, um skyldutryggingu lífeyrisréttinda og starfsemi lífeyrissjóða, með síðari breytingum (fjárfestingarheimildir lífeyrissjóða). 
Michaelas, N., Chittenden, F., og Poutziouris, P. (1999). Financial policy and capital structure choice in UK SMEs: Empirical evidence from company panel data. Small Business Economics, 12 (2), 113-130. DOI: 10.1023/A:1008010724051.

Modigliani, F., og Miller, M. H. (1958). The Cost of Capital, Corporation Finance and the Theory of Investment. The American Economic Review, 48(3), 261-297. http://www.jstor.org/stable/1809766.

Modigliani, F., og Miller, M. H. (1963). Corporate Income Taxes and the Cost of Capital: A Correction. The American Economic Review, 53(3), 433-443. http://www.jstor.org/stable/1809167.

Myers, S. C. (1984). The capital structure puzzle. The Journal of Finance, 39(3), 575-592. http://links.jstor.org/sici?sici=0022-1082\%28198407\%2939\%3A3\%3C575\%3ATCSP \%3E2.0.CO\%3B2-\%23.

Myers, S. C. (2003). Financing of Corporations. Í G. M. Constantinides, M. Harris og R. M. Stulz (ritstj.), Handbook of the Economics of Finance, 1(1) 1. útg. Elsevier, Amsterdam, bls. 215-254. http://EconPapers.repec.org/RePEc:eee:finhes:1.

Myers, S. C., og Majluf, N. S. (1984). Corporate financing and investment decisions when firms have information that investors do not have. Journal of Financial Economics, 13, 187-221. DOI: 10.1016/0304-405X(84)90023-0.

Nasdaq OMX Nordic (2015). Indexes OMX Iceland 8, Historical prices. Sótt 22. desember 2015 af vef Nasdaq OMX Iceland: http://www.nasdaqomxnordic.com/indexes/historical_ prices?Instrument=IS0000018885.

OECD (2015a). Assessment and recommendations, kafli í OECD Economic Surveys: Iceland 2015, 13-42. París: OECD Publishing. DOI: http://dx.doi.org/10.1787/ eco_surveys-isl-2015-3-en.

OECD (2015b). Supporting long-term growth by improving the business environment, kafli í OECD Economic Surveys: Iceland 2015, 81-102. París: OECD Publishing. DOI: http://dx.doi.org/10.1787/eco_surveys-isl-2015-6-en.

OECD (2015c). OECD Business and Finance Outlook 2015. París: OECD Publishing. DOI:10.1787/9789264234291-en.

Páll Harðarson (1. október, 2015). Ný vísitala í kauphöllinni. Tilkynning frá forstjóra Nasdaq Iceland, haft eftir mbl.is http://www.mbl.is/vidskipti/frettir/ 2015/10/01/ny_visitala_i_kauphollinni/.

Petersen, C.V., og Plenborg, T. (2012). Financial Statement Analysis: Valuation, credit analysis and executive compensation. Essex: Pearson Education Limited.

Proença, P., Laureano, R. M., og Laureano, L. M. (2014). Determinants of Capital Structure and the 2008 Financial Crisis: Evidence from Portuguese SMEs. Procedia Social and Behavioral Sciences, 150, 182-191. DOI: 10.1016/j.sbspro.2014.09.027.

Rajan, R., og Zingales, L. (1995). What do we know about capital structure? Some evidence from international data. Journal of Finance, 50, 1421-1460. DOI: $10.2307 / 2329322$.

Samkeppniseftirlitið (2011). Samkeppnin eftir hrun, 2/2011. Sótt 26. júní 2015 af vef Samkeppniseftirlitsins: http://www.samkeppni.is/media/skyrslur2011/Samkeppnin_eftir_hrun.pdf.

Samkeppniseftirlitið (2012). Endurreisn fyrirtækja 2012. Aflaklær eða uppvakningar?, 3/2012. Sótt 11. apríl 2015 af vef Samkeppniseftirlitsins: http://www.samkeppni.is/media/skyrslur-2012/Skyrsla_3_2012_Endurreisn_fyrirtaekja_ Aflaklaer_eda_uppvakningar.pdf. 
Samkeppniseftirlitið (2013). Er týndi áratugurinn framundan? Öflug samkeppni læknar stöðnun, 3/2013. Sótt 1. október 2015 af vef Samkeppniseftirlitsins: http://www.samkeppni.is/ media/skyrslur-2013/Skyrsla_3_2013_Er_tyndi_aratugurinn_framundan.pdf.

Seðlabanki Íslands (2011a). Fjármálastöðugleiki, 1. Sótt 18. september 2015 af vef Seðlabanka Íslands: http://www.sedlabanki.is/library/Skraarsafn/ Fjármálastöðugleiki/FS_2011_1.pdf.

Seðlabanki Íslands (2011b). Peningamál, 2, Próun og horfur í efnahags- og peningamálum. Sótt 22. desember 2015 af vef Seðlabanka Íslands: http://sedlabanki.is/ lisalib/getfile. aspx?itemid $=8644$.

Seðlabanki Íslands (apríl, 2015a). Gengi, Tímarađir í excel. Sótt 29. apríl 2015 af vef Seðlabanka Íslands: http://www.sedlabanki.is/gengi/timaradir-i-excel/.

Seðlabanki Íslands (2015b). Fjármálastöðugleiki, 2. Sótt 29. nóvember 2015 af vef Seðlabanka Íslands: http://www.sedlabanki.is/library/Skraarsafn/Fjármálastöðugleiki/20152/FS_2015-2.pdf.

Seðlabanki Íslands (2015c). Meginvextir SÍ: Vextir á veðlánum. Sótt 22. desember 2015 af vef Seðlabanka Íslands: http://www.sedlabanki.is/annad-efni/meginvextir-si/.

Shyam-Sunder, L., og Myers, S. (1999). Testing static tradeoff against pecking order models of capital structure. Journal of Financial Economics, 51, 219-244. DOI: 10.1016/S0304-405X(98)00051-8.

Sogorb-Mira, F. (2005). How SME uniqueness affects capital structure: Evidence from a 1994- 1998 Spanish data panel. Small Business Economics, 25 (5), 447-457. DOI: 10.1007/s11187-004-6486-8.

Steinn Friðriksson (2015). Fjármagnsskipan og fjárhagsleg staða 500 veltumestu fyrirtækja landsins. Efnahagsmál, 7, 3-28. Sótt 15. apríl 2015 af vef Seðlabanka Íslands: http://www.sedlabanki.is/library/Skraarsafn/Efnahagsmál/Efnahagsmal\%20rit\%207.pdf.

Viðskiptaráð Íslands (júní, 2009). Hugsum smátt - Lítil og meðalstór fyrirtæki. Sótt 11. apríl 2015 af vef Viðskiptaráðs Íslands: http://www.vi.is/files/SMEweb_1749858511.pdf.

Viðskiptaráð Íslands (febrúar, 2010). Er framtíð fyrir íslenskt atvinnulif? Samkeppnishæfni og rekstrarumhverfi. Sótt 20. október 2015 af vef Viðskiptaráðs Íslands:

http://www.vi.is/files/2010.02.16\%20Skyrsla\%20-\%20Er\%20framtid\%20 fyrir\%20islenskt\%20atvinnulif_894621128.pdf.

Voordeckers, W., og Steijvers, T. (2006). Business collateral and personal commitments in SME lending. Journal of Banking and Finance, 30, 3067-3086. DOI: 10.1016/j.jbankfin.2006.05.003.

Pórólfur Matthíasson (2012). Geta yfirskuldsett fyrirtæki verið lífvænleg? Pjóðarspegillinn 2012. Rannsóknir í félagsvísindum XII. Erindi flutt á rádstefnu í október 2012. Sótt 14. september af vef Skemmunnar: http://skemman.is/is/stream/get/1946/13332/31990/1/ ThorolfurMatthiasson_yfirskuldsett_fyrirtaeki_lifvaen.pdf.

Walsh, C. (2002). Key management ratios, 3. útg. London: Prentice Hall.

Weygandt, J. J., Kieso, D. E., og Kimmel, P. D. (2002). Managerial Accounting: Tools for Business Decision Making, 2. útg. New York: Wiley.

World Economic Forum (2009). The Global Competitiveness Report 2008-2009. Sótt 15. október 2015 af vef World Economic Forum: http://www3.weforum.org/docs/ WEF_GlobalCompetitivenessReport_2008-09.pdf.

Wooldridge, J. M. (2013). Introductory Econometrics: A modern approach, 5. útg. Canada: SouthWestern, Cengage Learning. 


\section{Viðauki. Skilgreiningar á kennitölum og viðmið.}

\begin{tabular}{|c|c|c|}
\hline Kennitala & & Viðmið (ef við á) \\
\hline \multicolumn{3}{|l|}{ Skuldsetning: } \\
\hline \multirow[t]{3}{*}{ Skuldahlutfall } & $\frac{\text { Skuldir }}{\text { Eignir }}$ & $\begin{array}{l}\text { Heildarskuldir, p.e. langtíma- og skammtímaskuldir, sem } \\
\text { hlutfall af heildareignum. }\end{array}$ \\
\hline & & $\begin{array}{l}\text { Ef }<0,5 \text { pá eru eignir að mestu fjármagnaðar með eigin fé, en } \\
\text { með skuldum ef }>0,5 \text {. }\end{array}$ \\
\hline & & Viðmið er u.p.b. 0,6-0,7, en ath. pó atvinnugrein og stærð. \\
\hline \multirow{2}{*}{$\begin{array}{l}\text { Hlutfall skulda af } \\
\text { eigin fé }\end{array}$} & Skuldir & Heildarskuldir sem hlutfall af eigin fé. \\
\hline & Eigið fé & $\begin{array}{l}\text { Viðmið er u.p.b. } 1 \text { p.e. ef skuldir=eigið fé, en 1,5-2 getur verið } \\
\text { ásættanlegt. }\end{array}$ \\
\hline \multirow[t]{2}{*}{ LTsk/fjármagn } & Langtímaskuldir & \multirow[t]{2}{*}{ Langtímaskuldir sem hlutfall af fjármagni. } \\
\hline & $\overline{\text { (Langtímaskuldir + eigið fé) }}$ & \\
\hline \multirow[t]{2}{*}{ Hreinar skuldir } & Skuldir & Nálgun á skuldum við lánardrottna. Heildarskuldir að \\
\hline & $\begin{array}{l}\text { - veltufjármunir } \\
\text { - skuldbindingar }\end{array}$ & $\begin{array}{l}\text { frádregnu handbæru fé og skammtímaverðbréfum, ásamt } \\
\text { skuldaliðum s.s. eftirlaunaskuldbindingum. }\end{array}$ \\
\hline
\end{tabular}

Eiginfjárhlutfall:

$\frac{\text { Eigið fé }}{\text { Eignir }} \quad$ Eigið fé sem hlutfall af heildareignum.

Hátt hlutfall gefur til kynna lægri vaxtagreiðslur og meira handbært fé. Lágt hlutfall pýðir miklar skuldir og erfiðleika við að fjármagna sig á góðum kjörum.

\begin{tabular}{|c|c|c|}
\hline \multicolumn{3}{|l|}{ Greiðsluhæfi: } \\
\hline Skuldir/EBITDA* & $\frac{\text { Skuldir }}{\text { EBITDA }}$ & $\begin{array}{l}\text { Heildarskuldir sem hlutfall af hagnaði fyrir vexti, skatta, } \\
\text { afskriftir og fyrninga. }\end{array}$ \\
\hline Veltufjárhlutfall & $\frac{\text { Veltufjármunir }}{\text { Skammtímaskuldir }}$ & \\
\hline Reiðufjárhlutfall* & $\frac{\text { Handbært fé }}{\text { Skammtímaskuldir }}$ & \\
\hline \multicolumn{3}{|l|}{ Arðsemi: } \\
\hline $\begin{array}{l}\text { EBITDA } \\
\text { Return on Assets* }\end{array}$ & $\frac{\text { EBITDA }}{\text { Heildareignir }}$ & $\begin{array}{l}\text { Hagnaður fyrir vexti, skatta, afskriftir og fyrninga sem } \\
\text { hlutfall af heildareignum }\end{array}$ \\
\hline
\end{tabular}

